\title{
Grade-dependent effects on cell cycle progression and apoptosis in response to doxorubicin in human bladder cancer cell lines
}

\author{
DIMITRIOS J. STRAVOPODIS ${ }^{1}$, PANAGIOTIS K. KARKOULIS ${ }^{2}$, EUMORPHIA G. KONSTANTAKOU ${ }^{1}$, \\ SOPHIA MELACHROINOU ${ }^{2}$, ANTONIS D. LAMPIDONIS ${ }^{2}$, DIMITRA ANASTASIOU ${ }^{2}$, STEFANOS KACHRILAS $^{2}$, \\ NIKI MESSINI-NIKOLAKI ${ }^{1}$, ISSIDORA S. PAPASSIDERI ${ }^{1}$, GERASIMOS ARAVANTINOS ${ }^{3}$, \\ LUKAS H. MARGARITIS $^{1}$ and GERASSIMOS E. VOUTSINAS ${ }^{2}$

\begin{abstract}
${ }^{1}$ Department of Cell Biology and Biophysics, Faculty of Biology, University of Athens, Panepistimiopolis, Zografou, 15784 Athens; ${ }^{2}$ Laboratory of Environmental Mutagenesis and Carcinogenesis, Institute of Biology, National Center for Scientific Research (NCSR) 'Demokritos', 15310 Athens; ${ }^{3}$ 3rd Clinic of Pathology-Oncology, ‘Agioi Anargyroi' Oncology Hospital, Ilion, 13122 Athens, Greece
\end{abstract}

Received June 26, 2008; Accepted September 5, 2008

DOI: 10.3892/ijo_00000137

\begin{abstract}
Doxorubicin is an important component of combination therapy for muscle-invasive urinary bladder cancer. Treatment with this topoisomerase II poison is able to interfere with cell cycle progression and lead to cancer cell death. Using FACS analysis, Western immunoblotting and semi-quantitative RT-PCR, we studied the effects of doxorubicin on cell cycle progression and apoptosis, and also explored the possibility of using groups of genes as biomarkers of prognosis and/or response to doxorubicin treatment in human urinary bladder cancer cells. Doxorubicin induced dose-dependent G2/M and/or G1/S cell cycle arrest, followed by grade- and dose-dependent reduction in the amount of the cytosolic trimeric form of FasL, activation of Caspase-8, Caspase-9, Caspase-3, cleavage of PARP, Lamin A/C, Bcl- $\mathrm{X}_{\mathrm{L} / \mathrm{S}}$ and interestingly Hsp90, and finally cell death. Data presented
\end{abstract}

Correspondence to: Dr Gerassimos E. Voutsinas, Institute of Biology, NCSR 'Demokritos', 15310 Athens, Greece

E-mail: mvoutsin@bio.demokritos.gr

Abbreviations: B-CLL, B-cell chronic lymphocytic leukemia; BSA, bovine serum albumin; DMEM, Dulbecco's modified Eagle's medium; ECL, enhanced chemiluminescence; ER, endoplasmic reticulum; FasL, Fas ligand (m, membrane; s, soluble); FBS, fetal bovine serum; HCC, hepatocellular carcinoma; Hsp90, heat shock protein 90; IAPs, inhibitors of apoptosis proteins; MEFs, mouse embryo fibroblasts; MMLV, mouse Moloney leukemia virus; MMP-7, matrix metalloproteinase-7; MTT, methylthiazole tetrazolium; NSCLC, non-small cell lung cancer; PARP, poly(ADP-ribose) polymerase; PBS, phosphate-buffered saline; PCR, polymerase chain reaction; PMSF, phenylmethylsulfonyl fluoride; PSA, prostatespecific antigen; Rb, retinoblastoma; RCC, renal cell cancer; RTPCR, reverse transcription-PCR; SCLC, small cell lung cancer; SDS, sodium dodecyl sulfate; TBST, Tris-buffered saline - Tween-20; TRAIL, tumor necrosis factor-related apoptosis-inducing ligand

Key words: apoptosis, bladder, cancer, cell cycle, chemotherapy, doxorubicin here also suggest the use of the expression patterns of $C y c l i n-$ E2, Cyclin-F, p63, p73, FasL, TRAIL, Tweak, Tweak-R, XAF-1, $O P G$ and $B o k$ genes for identification of the differentiation grade, and Cyclin-B2, GADD45A, p73, FasL, Bik, Bim, TRAIL, Fas, Tweak-R, XAF-1, Bcl-2, Survivin, OPG, DcR2 and $B c l-X_{L}$ genes for the detection of response to doxorubicin in human bladder cancer cells.

\section{Introduction}

A significant percentage of urinary bladder cancer patients ( $20-30 \%)$ present with an aggressive tumor of low differentiation, where invasion of the basement membrane has already occurred. The rest of the bladder cancer patients show up with superficial, highly differentiated and non-invasive papillary tumors, $15-30 \%$ of which, nevertheless, after transurethral resection of the primary tumor, will develop invasive disease. Eventually, in less than two years, more than $50 \%$ of the invasive tumors will develop distant metastases $(1,2)$. This apparent heterogeneity in bladder cancer is thought to be mainly due to discrete genetic alterations involved in tumor development and progression (3-5). Further elucidation of the course of tumor progression and grade-dependent response to therapy could, therefore, be of great help in the classification of tumors into distinct clinically relevant groups for an effective individualized treatment that should have a significant impact on the management of the disease.

Topoisomerase II has proved to be a successful drug target because of its indispensable cellular function and its lack of biological redundancy. Topoisomerases II $\alpha$ and IIß are ATPdependent endonucleases, also bearing ligase activities. Functioning mainly as homodimers, they generate cleavages in both DNA strands and then they covalently bind to the new DNA 5 '-ends ligating the double strand nicks with concurrent ATP hydrolysis. Due to this mode of action, topoisomerase II activity is required at several points in DNA metabolism, such as transcription, replication, chromosome condensation and segregation $(6,7)$. Topoisomerase II $\alpha$ expression was shown to be regulated during the cell cycle, becoming detectable in late G1- 
phase and then gradually increasing to a peak in G2/M, while the enzyme was found to be a reliable proliferation marker (8).

Doxorubicin constitutes an important component of combination therapy for muscle-invasive transitional cell urinary bladder cancer $(9,10)$. This drug belongs to the group of anthracycline antibiotics and functions as a topoisomerase II poison. Its cytostatic and cytotoxic actions have been attributed to a number of distinct mechanisms, such as intercalation into DNA with consequent inhibition of macromolecular biosynthesis (11), free radical formation with consequent induction of DNA damage or lipid peroxidation $(12,13)$, DNA binding and alkylation (14), DNA cross-linking (15), interference with DNA unwinding or DNA strand separation and helicase activity (16), direct membrane effects (17) and, of course, topoisomerase II inhibition (6). Nevertheless, at clinically relevant concentrations there are serious arguments against the action of doxorubicin through the pre-mentioned mechanisms, with topoisomerase II functional inhibition being the only exception (18). When targeting topoisomerase II, doxorubicin acts by stabilizing a reaction intermediate in which DNA strands are first cleaved and then covalently linked to certain tyrosine residues of the enzyme, eventually impeding DNA resealing. Therefore, the formation of doxorubicinDNA-topoisomerase II ternary complexes leads to the generation of irreversible double strand breaks and finally to the induction of cell death $(6,8)$. Although the molecular events from the generation of double strand breaks to the implementation of the cell death process by necrosis, apoptosis and/or autophagy are still insufficiently explored, several observations unambiguously demonstrate that the drug-mediated inhibition of topoisomerase II is able to induce distinct modes of arrest at different checkpoints of the cell cycle $(19,20)$. Topoisomerase II poisons appear to be particularly toxic during Sphase, when replication forks and transcription complexes are both present, whereas cell cycle arrest at G1/S and a transient S-phase block have also been identified, independently of the p53 status of the cells (20). Besides the various cell cycle blocks, inhibitors of topoisomerase II have been reported to induce both the stress-activated protein kinase and the apoptotic pathways. In the whole process, activation of JNK and p38, but not ERK1 or ERK2, kinases was involved, with subsequent induction of a series of stereotypic morphological changes characteristic of apoptosis. These included loss of cell volume, hyperactivity of the plasma membrane, condensation of peripheral heterochromatin, and cleavage of the nucleus and cytoplasm into multiple membrane-enclosed bodies (21). The implementation of the apoptotic program seems to be regulated, among others, by FasL expression, release of Cytochrome $\mathrm{c}$ to the cytosol, activation of Caspase-3 and cleavage of genomic DNA into high molecular weight fragments (22).

In this context, herein, we have thoroughly studied the regulation of cell cycle progression and apoptosis in response to different doses of doxorubicin treatment in two human urinary bladder cancer cell lines of different malignancy grade, namely RT4 (grade I) and T24 (grade III). Moreover, the potential of some of the examined genes to serve as putative biomarkers of prognosis as well as for the reliable monitoring of response to doxorubicin treatment was investigated in RT4 and T24 cancer cells.

\section{Materials and methods}

Drugs and reagents. The chemotherapeutic drug doxorubicin was obtained from EBEWE Arzneimittel GmbH (Unterach, Austria), while taxol was supplied by Bristol-Myers Squibb Company (NY, USA). Polyclonal and monoclonal antibodies against Caspase-3 (polyclonal: \#9662), Caspase-8 (monoclonal: \#9746), Caspase-9 (polyclonal: \#9502), PARP (polyclonal: \#9542), Lamin A/C (polyclonal: \#2032), Bcl-X $\mathrm{L}_{\mathrm{L} / \mathrm{S}}$ (polyclonal: \#2762) and Pan-Actin (polyclonal: \#4968) were purchased from Cell Signaling Technology Inc. (Hertfordshire, UK), whereas antibodies against FasL (polyclonal: SC-834) and Hsp90//B (monoclonal: SC-13119) were supplied by Santa Cruz Biotechnology Inc. (CA, USA). ECL Western blot detection reagents were obtained from Amersham Life Sciences (Buckinghamshire, UK). Oligonucleotide primers were synthesized by Operon (CA, USA) and Metabion (Martinsried, Germany). All other chemicals were of analytical grade from Sigma-Aldrich (MO, USA), Fluka (Hannover, Germany) and AppliChem GmbH (Darmstadt, Germany).

Cell lines and culture conditions. The present study was performed on two human urinary bladder cancer cell lines, namely RT4 and T24, both originating from transitional cell carcinomas. RT4 cells harbor a wild-type p53 gene, they are derived from grade I tumor and were obtained from the European Collection of Animal Cell Cultures (Salisbury, UK), whereas T24 cells contain a p53 gene mutation, they are derived from grade III tumor and were a generous gift from Professor J.R. Masters (Prostate Cancer Research Centre, Institute of Urology, University College, London, UK). Cells were maintained in DMEM, supplemented with L-glutamine $(2 \mathrm{mM})$, penicillin $(100 \mathrm{U} / \mathrm{ml})$, streptomycin $(100 \mu \mathrm{g} / \mathrm{ml})$, sodium pyruvate $(1 \mathrm{mM})$, sodium bicarbonate $(50 \mathrm{mM})$, non-essential amino acids (1X) and 10\% heat-inactivated FBS, at $37^{\circ} \mathrm{C}$ in a humidified $5 \% \mathrm{CO}_{2}$ atmosphere and were successively split with the help of $0.25 \%$ trypsin plus $0.02 \%$ EDTA. All cell culture media and reagents were supplied by Biochrom AG (Berlin, Germany).

MTT cytotoxicity assay. The MTT assay is based on the conversion of the yellow methylthiazole tetrazolium salt [3(4,5-dimethylthiazol-2-yl)-2,5-diphenyl tetrazolium bromide] to purple formazan crystals by metabolically active cells containing functional mitochondria and provides a quantitative determination of viable cells. Cells were seeded at a density of 15-20,000 per well into 48-well plates and allowed to adhere for $24 \mathrm{~h}$. Then, cells were treated with various drug concentrations for $24 \mathrm{~h}$. The next day, cells were washed twice with PBS and incubated for $4 \mathrm{~h}$ in MTT solution at $37^{\circ} \mathrm{C}$ in a humidified $5 \% \mathrm{CO}_{2}$ atmosphere. The formazan crystals that formed were solubilized in $200 \mu 1$ of isopropanol with the help of a shaking platform at room temperature for $10 \mathrm{~min}$. The spectrophotometric absorbance was measured in an ELISA microtiter plate reader (Dynatech MR5000, Dynatech Laboratories, VA, USA) at $550 \mathrm{~nm}$, using measurement at $630 \mathrm{~nm}$ as reference. Absorbance given by untreated cells was taken as $100 \%$ cell survival. Each assay was repeated at least three times using three wells per drug concentration in each experimental condition. 
Cell cycle analysis. For analysis of the cell cycle, RT4 and T24 cells were seeded at a density of $5 \times 10^{5}$ cells approximately in $30 \mathrm{~mm}$ plates and allowed to grow for $24 \mathrm{~h}$. The next day, appropriate drug treatments were carried out for $24 \mathrm{~h}$ and the cells were washed with ice-cold phosphate-buffered saline (PBS) and collected in Falcon tubes after having been scraped with the help of rubber policemen. After two washes in PBS at $4^{\circ} \mathrm{C}$, cells were fixed in $1 \%$ methanol-free formaldehyde for $20 \mathrm{~min}$, washed again in ice-cold PBS and left overnight in $70 \%$ ethanol at $-20^{\circ} \mathrm{C}$ to dehydrate. The day after, the cells were washed twice in PBS, transferred in Eppendorf tubes, resuspended in $1 \mathrm{ml}$ of $0.1 \%$ Triton $\mathrm{X}-100$, washed twice with PBS and incubated for $30 \mathrm{~min}$ in $500 \mu \mathrm{l}$ of propidium iodide solution $(50 \mu \mathrm{g} / \mathrm{ml})$ containing $250 \mu \mathrm{g}$ of DNase-free RNase A. Then, cells were analyzed using flow cytometry, in a Beckton Dickinson's FACScaliber (CA, USA) at $542 \mathrm{~nm}$, using the Modfit software program.

Whole cell extract preparations. Following the indicated drug treatments and after mild scraping, cells were transferred in Falcon tubes, washed three times with ice-cold PBS and immediately resuspended in freshly prepared ice-cold $1 \mathrm{X}$ lysis buffer (10 mM Tris-base, $50 \mathrm{mM} \mathrm{NaCl}, 5 \mathrm{mM} \mathrm{Na}{ }_{2}$ EDTA $2 \mathrm{H}_{2} \mathrm{O}, 1 \%$ Triton $\mathrm{X}-100,30 \mathrm{mM} \mathrm{Na} \mathrm{P}_{2} \mathrm{O}_{7} \cdot 10 \mathrm{H}_{2} \mathrm{O}, 50 \mathrm{mM}$ $\mathrm{NaF}, 0.2 \mathrm{mM} \mathrm{Na}_{3} \mathrm{VO}_{4} \cdot \mathrm{H}_{2} \mathrm{O}$ and $1 \mathrm{mM}$ PMSF, adjusted to $\mathrm{pH} 7.6$ at $4^{\circ} \mathrm{C}$ ), wherein they remained for $2 \mathrm{~h}$ at $4^{\circ} \mathrm{C}$, under conditions of smooth shaking. The lysates were clarified by centrifugation at 12,500 rpm for $30 \mathrm{~min}$. The clear supernatant was transferred to a new Eppendorf tube, protein content was quantitated by the method of Bradford and, after the addition of an equal volume of $2 \mathrm{X}$ Laemmli buffer (100 mM Tris- $\mathrm{HCl}$, pH 6.8, 4\% SDS, 200 mM DTT, 20\% glycerol and 0.2\% bromophenol blue), aliquots of the produced whole cell extracts were stored at $-30^{\circ} \mathrm{C}$ for not more than six months.

Immunoblotting. Whole cell extracts $(\sim 30 \mu \mathrm{g})$ were resolved under denaturing conditions by SDS-polyacrylamide gel electrophoresis in 10-15\% gels and subsequently electrotransferred overnight onto nitrocellulose membranes of $0.45 \mu \mathrm{m}$ pore size (Schleicher and Schuell GmbH, Dassel, Germany). In order to avoid non-specific antibody interactions, membrane blocking was performed in TBST (20 mM Tris$\mathrm{HCl}, \mathrm{pH} 7.6,137 \mathrm{mM} \mathrm{NaCl}$ and $0.1 \%$ Tween-20) containing $5 \%$ non-fat dry milk (or 5\% BSA grade $\mathrm{V}$ where appropriate) at room temperature for $1.5 \mathrm{~h}$, under constant shaking conditions. After three brief washings with TBST, the membranes were incubated with the appropriate antibodies at room temperature for $1.5 \mathrm{~h}$, followed by an overnight incubation at $4^{\circ} \mathrm{C}$, under constant shaking conditions. After six washings with TBST of $10 \mathrm{~min}$ each at room temperature, the membranes were incubated with the appropriate anti-mouse or anti-rabbit HRPconjugated secondary antibody at room temperature for $2 \mathrm{~h}$, under constant shaking conditions. After extensive washings (6 times x 15 min each) with TBST at room temperature, the examined antibodies were detected using an ECL Western blotting kit according to manufacturer's instructions.

RT-PCR analysis. After the appropriate drug incubations, total RNA from both control and treated cells was extracted using TRIzol reagent (Invitrogen, CA, USA), according to the
(A)

RT4

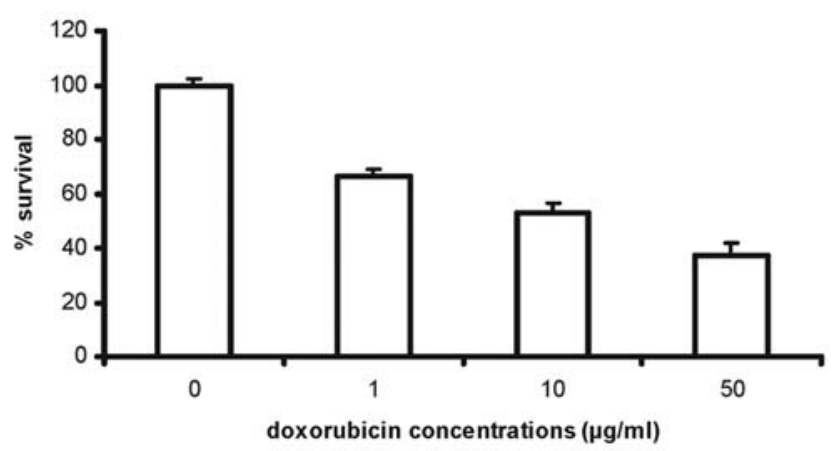

(B)

T24

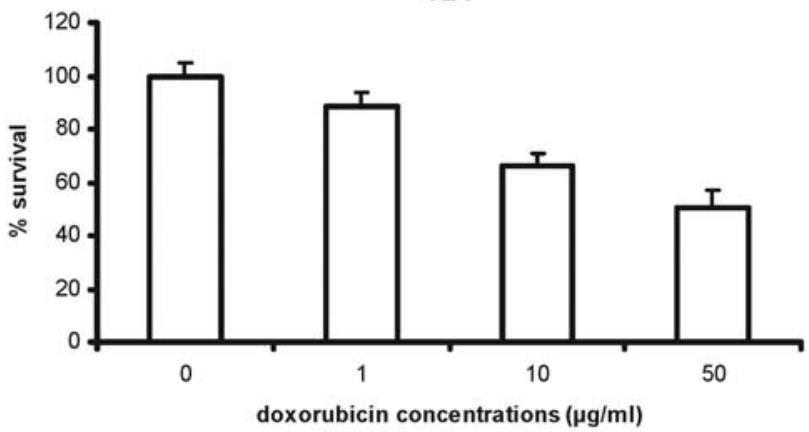

Figure 1. Dose-dependent cell death induced by $0,1,10$ and $50 \mu \mathrm{g} / \mathrm{ml}$ doxorubicin for $24 \mathrm{~h}$ in human urinary bladder cancer cell lines. (A), RT4 (grade I) cells. (B), T24 (grade III) cells. Each concentration was tested in three individual wells, while each different experiment was carried out three times. Bars mark standard deviation values.

manufacturer's instructions. Total RNA $(1 \mu \mathrm{g})$ was used for first strand cDNA synthesis in a final volume of $20 \mu \mathrm{l}$, using an Oligo-dT (20mer) primer (Invitrogen) and MMLV reverse transcriptase (Invitrogen). After bringing the $20 \mu \mathrm{l}$ of the final cDNA preparation to $100 \mu 1$ (i.e., dilution 1:5), $1 \mu 1$ of cDNA solution was amplified by PCR in a total volume of $25 \mu \mathrm{l}$, using cDNA-specific primers corresponding to the various mRNA species examined in the present study. The obtained PCR fragments were resolved in 2-3\% agarose gels, according to standard procedures. The respective names, nucleotide sequences, molecular sizes of amplified products, annealing temperatures and numbers of reiterative PCR cycles for all the utilized cDNA primers are summarized in Table I.

\section{Results}

Grade-specific sensitivity of human bladder cancer cell lines to doxorubicin. To quantify the biological effect of doxorubicin on the survival of human urinary bladder cancer cell lines RT4 (grade I) and T24 (grade III), an MTT assay was performed on cells incubated with doxorubicin for $24 \mathrm{~h}$. In both cases, a dose-dependent significant decrease in cell viability was observed. In RT4 cells, viability decreased to $\sim 66 \%, 53 \%$ and $37 \%$ of control (mean values) in the concentrations of 1,10 and $50 \mu \mathrm{g} / \mathrm{ml}$ of doxorubicin, respectively, whereas in $\mathrm{T} 24$ cells, in the same concentrations, the percentage of survival dropped to $\sim 88 \%, 66 \%$ and $51 \%$ of control (mean values) (Fig. 1). These data strongly suggest that both cell lines display a dose-dependent sensitivity to 
Table I. Names, primer sequences, sizes of PCR products and PCR conditions for genes involved in the regulation of cell cycle and apoptosis included in the RT-PCR-based expression analysis.

\begin{tabular}{|c|c|c|c|c|}
\hline Gene name & Primer sequence & $\begin{array}{l}\text { Length of PCR } \\
\text { product (bp) }\end{array}$ & $\begin{array}{c}\text { Temperature } \\
\left({ }^{\circ} \mathrm{C}\right)\end{array}$ & No. of cycles \\
\hline Cyclin-E1 & $\begin{array}{l}\text { F: 5'-GTA TCA GTG GTG CGA CAT AG-3' } \\
\text { R: 5'-ACA ACA TGG CTT TCT TTG CTC-3' }\end{array}$ & 188 & 55 & 30 \\
\hline Cyclin-E2 & $\begin{array}{l}\text { F: 5'-GGA GTG GGA CAG TAT TTC AG-3' } \\
\text { R: 5'-TTT TCA GTG CTC TTC GGT GG-3' }\end{array}$ & 259 & 55 & 30 \\
\hline Cyclin-B1 & $\begin{array}{l}\text { F: 5'-CTA CCT TTG CAC TTC CTT CG-3' } \\
\text { R: 5'-CCA TGA CTA CAT TCT TAG CC-3' }\end{array}$ & 268 & 54 & 30 \\
\hline Cyclin-B2 & $\begin{array}{l}\text { F: 5'-GTC TCA GAA GGT TCT AGG AC-3' } \\
\text { R: 5'-GGA GTT TGC TGC TTG CAT AC-3' }\end{array}$ & 176 & 53 & 30 \\
\hline Cyclin-F & $\begin{array}{l}\text { F: 5'-GAG AAC AGC CTC CAG GAA GA-3' } \\
\text { R: 5'-TTC AGG TAG ACC ACG GTG AC-3' }\end{array}$ & 209 & 57 & 30 \\
\hline Cyclin-D & $\begin{array}{l}\text { F: 5'-GTG TCC TAC TTC AAA TGT GTG C-3' } \\
\text { R: 5'-GGA GTT GTC GGT GTA GAT GC-3' }\end{array}$ & 270 & 57 & 30 \\
\hline $\mathrm{p} 21^{\text {Cip1 }}$ & $\begin{array}{l}\text { F: 5'-CCT CTT CGG CCC AGT GGA C-3' } \\
\text { R: 5'-CCG TTT TCG ACC CTG AGA G-3' }\end{array}$ & 367 & 60 & 28 \\
\hline GADD45A & $\begin{array}{l}\text { F: 5'-CGT TTT GCT GCG AGA ACG AC-3' } \\
\text { R: 5'-GAA CCC ATT GAT CCA TGT AG-3' }\end{array}$ & 236 & 54 & 30 \\
\hline p53 & $\begin{array}{l}\text { F: 5'-GGG ACG GAA CAG CTT TGA GG-3' } \\
\text { R: 5'-TTC AGC TCT CGG AAC ATC TCG-3' }\end{array}$ & 240 & 59 & 30 \\
\hline p63 & $\begin{array}{l}\text { F: 5'-CGA GGT TGG GCT GTT CAT CA-3' } \\
\text { R: 5'-ACT GTA GAG GCA CTG CTT GG-3' }\end{array}$ & 217 & 57 & 30 \\
\hline p73 & $\begin{array}{l}\text { F: 5'-CAC AGT TCG GCA GCT ACA CC-3' } \\
\text { R: 5'-GTA AAT GCT CTG TAA CCC TTG G-3' }\end{array}$ & 246 & 56 & 30 \\
\hline GAPDH & $\begin{array}{l}\text { F: 5'-TGG TAT CGT GGA AGG ACT CAT GAC-3' } \\
\text { R: 5'-ATG CCA GTG AGC TTC CCG TTC AGC-3' }\end{array}$ & 189 & 55 & 28 \\
\hline FasL & $\begin{array}{l}\text { F: 5'-CTC TGG AAT GGG AAG ACA CC-3' } \\
\text { R: 5'-ACC AGA GAG AGC TCA GAT ACG-3' }\end{array}$ & 325 & 57 & 40 \\
\hline Bik & $\begin{array}{l}\text { F: 5'-CTG TAT GAG CAG CTC CTG G-3' } \\
\text { R: 5'-GAT GTC CTC AGT CTG GTC G-3' }\end{array}$ & 252 & 55 & 30 \\
\hline Bim & $\begin{array}{l}\text { F: 5'-TGT GAC AAA TCA ACA CAA ACC C-3' } \\
\text { R: 5'-AGT CGT AAG ATA ACC ATT CGT G-3' }\end{array}$ & 230 & 57 & 30 \\
\hline Caspase-3 & $\begin{array}{l}\text { F: 5'-GTG GTG TTG ATG ATG ACA TGG-3' } \\
\text { R: 5'-AAA GGA CTC AAA TTC TGT TGC C-3' }\end{array}$ & 224 & 57 & 30 \\
\hline TRAIL & $\begin{array}{l}\text { F: 5'-TGG CTA TGA TGG AGG TCC AG-3' } \\
\text { R: 5'-GTT GCC ACT TGA CTT GCC AG-3' }\end{array}$ & 249 & 57 & 30 \\
\hline Tweak & $\begin{array}{l}\text { F: 5'-GGA AAA CAC GGG CTC GAA GA-3' } \\
\text { R: 5'-CTT CAG GTA GAC AGC CTT CC-3' }\end{array}$ & 239 & 57 & 30 \\
\hline Fas & $\begin{array}{l}\text { F: 5'-GGA TGA ACC AGA CTG CGT G-3' } \\
\text { R: 5'-CTG CAT GTT TTC TGT ACT TCC-3' }\end{array}$ & $371 / 308$ & 55 & 30 \\
\hline DR4 & $\begin{array}{l}\text { F: 5'-CTT CAA GTT TGT CGT CGT CG-3' } \\
\text { R: 5'-ATG CAA CAA CAG ACA ATC AGC-3' }\end{array}$ & 519 & 55 & 30 \\
\hline
\end{tabular}


Table I. Continued.

\begin{tabular}{|c|c|c|c|c|}
\hline Gene name & Primer sequence & $\begin{array}{l}\text { Length of PCR } \\
\text { product (bp) }\end{array}$ & $\begin{array}{l}\text { Temperature } \\
\left({ }^{\circ} \mathrm{C}\right)\end{array}$ & No. of cycles \\
\hline DR5 & $\begin{array}{l}\text { F: 5'-CAA CAA GAC CTA GCT CCC CA-3' } \\
\text { R: 5'-ACG GCT GCA ACT GTG ACT C-3' }\end{array}$ & $497 / 417$ & 55 & 30 \\
\hline Tweak-R & $\begin{array}{l}\text { F: 5'-CTG GAC AAG TGC ATG GAC TG-3' } \\
\text { R: 5'-TGG TGA ACT TCT CTC TCC TG-3' }\end{array}$ & 199 & 55 & 30 \\
\hline Caspase-8 & $\begin{array}{l}\text { F: 5'-TCT GTG CCC AAA TCA ACA AG-3' } \\
\text { R: 5'-GCC ACC AGC TAA AAA CAT TCC-3' }\end{array}$ & 593 & 55 & 32 \\
\hline Caspase-10 & $\begin{array}{l}\text { F: 5'-CAT AGG ATT GGT CCC CAA CA-3' } \\
\text { R: 5'-CTT GAT ACG ACT CGG CTT CC-3' }\end{array}$ & 500 & 55 & 32 \\
\hline Bak-1 & $\begin{array}{l}\text { F: 5'-TCA TCG GGG ACG ACA TCA AC-3' } \\
\text { R: 5'-CAT GCT GGT AGA CGT GTA GG-3' }\end{array}$ & 198 & 57 & 30 \\
\hline Bax & $\begin{array}{l}\text { F: 5'-TCC ACC AAG AAG CTG AGC GAG-3' } \\
\text { R: 5'-GTC CAG CCC ATG ATG GTT CT-3' }\end{array}$ & 257 & 57 & 30 \\
\hline XAF-1 & $\begin{array}{l}\text { F: 5'-TCT CTT CCA AGT CAA GCT GC-3' } \\
\text { R: 5'-CTT TTG ATG AAG CTA ACC ACC-3' }\end{array}$ & 304 & 57 & 37 \\
\hline Puma & $\begin{array}{l}\text { F: 5'-CAG ACT GTG AAT CCT GTG CT-3' } \\
\text { R: 5'-ACA GTA TCT TAC AGG CTG GG-3' }\end{array}$ & 251 & 55 & 35 \\
\hline Noxa & $\begin{array}{l}\text { F: 5'-GTG CCC TTG GAA ACG GAA GA-3' } \\
\text { R: 5'-CCA GCC GCC CAG TCT AAT CA-3' }\end{array}$ & 258 & 55 & 35 \\
\hline $\mathrm{Bcl}-2$ & $\begin{array}{l}\text { F: 5'-TGT GGC CTT CTT TGA GTT CG-3' } \\
\text { R: 5'-AGC AGA GTC TTC AGA GAC AG-3' }\end{array}$ & 222 & 55 & 30 \\
\hline Survivin & $\begin{array}{l}\text { F: 5'-GAG CTG CAG GTT CCT TAT C-3' } \\
\text { R: 5'-ACA GCA TCG AGC CAA GTC AT-3' }\end{array}$ & 427 & 53 & 30 \\
\hline OPG & $\begin{array}{l}\text { F: 5'-TGC TGT TCC TAC AAA GTT TAC-3' } \\
\text { R: 5'-CTT TGA GTG CTT TAG TGC GTG-3' }\end{array}$ & 433 & 54 & 30 \\
\hline DcR2 & $\begin{array}{l}\text { F: 5'-CTT CAG GAA ACC AGA GCT TCC CTC-3' } \\
\text { R: 5'-TTC TCC CGT TTG CTT ATC ACA CGC-3' }\end{array}$ & 200 & 65 & 30 \\
\hline Bok & $\begin{array}{l}\text { F: 5'-GAT GAG CTG GAG ATG ATC CG-3' } \\
\text { R: 5'-CCT GCC TCA CAC AGT CCA C-3' }\end{array}$ & 199 & 57 & 30 \\
\hline Bid & $\begin{array}{l}\text { F: 5'-GAG TGC ATC ACA AAC CTA C-3' } \\
\text { R: 5'-GAT GTC TTC TTG ACT TTC AG-3' }\end{array}$ & 207 & 51 & 30 \\
\hline Bcl- $X_{L}$ & $\begin{array}{l}\text { F: 5'-CGG GCA TTC AGT GAC CTG AC-3' } \\
\text { R: 5'-TCA GGA ACC AGC GGT TGA AG-3' }\end{array}$ & 340 & 57 & 30 \\
\hline Mcl-1 & $\begin{array}{l}\text { F: 5'-TTG GTG CCT TTG TGG CTA AAC-3' } \\
\text { R: 5'-TGC CAA ACC AGC TCC TAC TC-3' }\end{array}$ & 230 & 57 & 30 \\
\hline FLIP & $\begin{array}{l}\text { F: 5'-AAT TCA AGG CTC AGA AGC GA-3' } \\
\text { R: 5'-GGC AGA AAC TCT GCT GTT CC-3' }\end{array}$ & 227 & 54 & 30 \\
\hline Smac/DIABLO & $\begin{array}{l}\text { F: 5'-AGC TGG AAA CCA CTT GGA TG-3' } \\
\text { R: 5'-GCT CTT CTA TCT GTG CTT CTG-3' }\end{array}$ & 192 & 55 & 30 \\
\hline cIAP-1 & $\begin{array}{l}\text { F: 5'-GCC TTT CTC CAA ACC CTC TT-3' } \\
\text { R: 5'-CAT TCG AGC TGC ATG TGT CT-3' }\end{array}$ & 356 & 55 & 29 \\
\hline Caspase-9 & $\begin{array}{l}\text { F: 5'-CTA ACA GGC AAG CAG CAA AG-3' } \\
\text { R: 5'-CTG GGA AAG TAG AGT AGG AC-3' }\end{array}$ & 777 & 55 & 30 \\
\hline
\end{tabular}


(A)
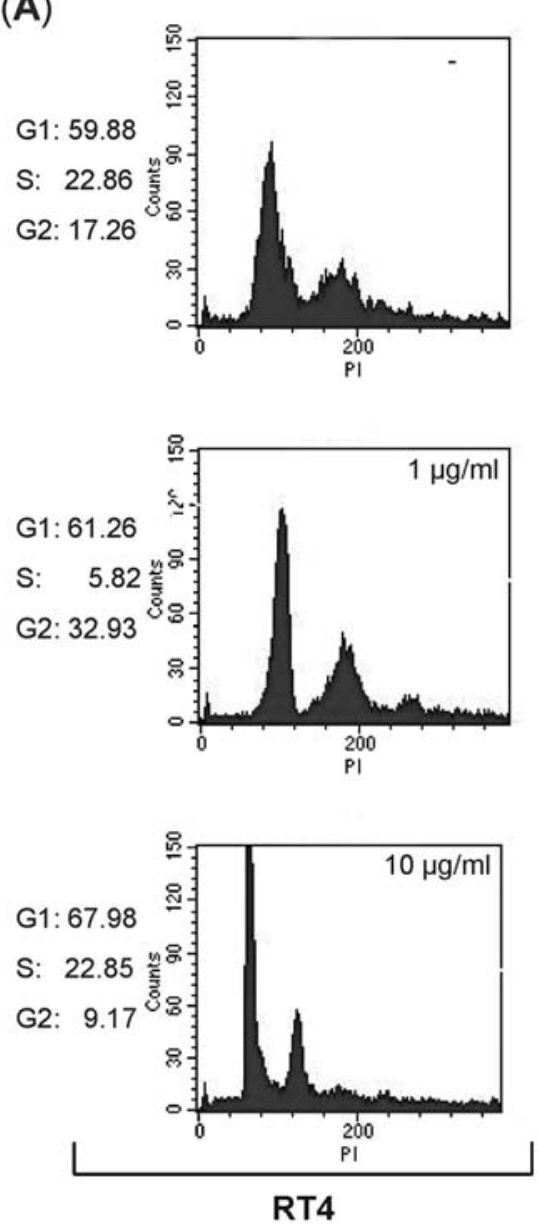

(B)
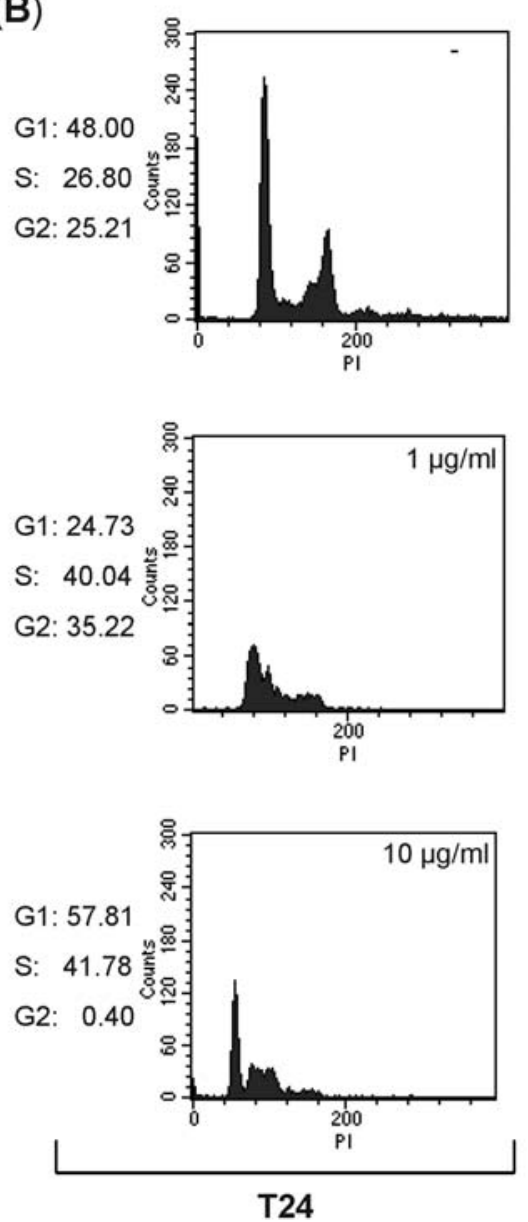

Figure 2. FACS analysis of cell cycle progression after treatment of human urinary bladder cancer cell lines with 0,1 and $10 \mu \mathrm{g} / \mathrm{ml}$ doxorubicin for $24 \mathrm{~h}$. (A), In RT4 cells, the lower concentration of doxorubicin induced a G2/M arrest, whereas the higher drug dose resulted in a G1/S arrest accompanied by an S-phase block. (B), In T24 cells, the lower drug concentration induced a G2/M arrest, whereas the higher dose resulted in a G1/S arrest, similarly to RT4 cells. In both cases, an S-phase block was accompanying the drug effect on the cell cycle.

doxorubicin, while T24 cells are more resistant to the drug than RT4.

Doxorubicin-induced inhibition of cell cycle progression. In order to investigate the cytotoxic effects of doxorubicin upon cell cycle course of RT4 and T24 cells, the DNA content of the cells was analyzed using flow cytometry and thus, the derived information was used to investigate the phase distribution of the cell cycle. RT4 cells revealed a cell cycle distribution typical of that for rapidly proliferating cells, with an average of $\sim 60 \%$ of cells featuring a $2 n$ DNA content, corresponding to G0/G1-phase, $\sim 17 \%$ of cells revealing a $4 n$ DNA content $(\mathrm{G} 2 / \mathrm{M})$ and $\sim 23 \%$ exhibiting a DNA content of between $2 n$ and $4 n$, corresponding to the S-phase (Fig. 2A, upper panel). A similar situation was observed in T24 cells as well, where an average of $48 \%$ of cells was found in G0/G1-phase, $\sim 25 \%$ of cells were in $\mathrm{G} 2 / \mathrm{M}$, whereas $\sim 27 \%$ of cells were detected in S-phase (Fig. 2B, upper panel).

Upon treatment of RT4 cells with the lower concentration ( $1 \mu \mathrm{g} / \mathrm{ml}$ ) of doxorubicin, an obvious $\mathrm{G} 2 / \mathrm{M}$ arrest was induced, with cells in $\mathrm{G} 2$ reaching $\sim 33 \%$ from $\sim 17 \%$ in the control (Fig. 2A, middle panel). Interestingly, the higher dose $(10 \mu \mathrm{g} /$ $\mathrm{ml}$ ) of doxorubicin induced G1/S arrest (G1-phase: from $\sim 60 \%$ in the control to $\sim 68 \%$ in treated cells), accompanied by a strong S-phase block (S-phase: from $\sim 6 \%$ in the lower dose to $\sim 23 \%$ in the higher dose) (Fig. 2A, bottom panel).

Similarly, in T24 cells, the lower doxorubicin concentration ( $1 \mu \mathrm{g} / \mathrm{ml}$ ) induced $\mathrm{G} 2 / \mathrm{M}$ arrest (G2-phase: from $\sim 25 \%$ in the control to $\sim 35 \%$ in the treated cells), accompanied by a clear S-phase block (S-phase: from $\sim 27 \%$ in the control to $\sim 40 \%$ in the treated cells) (Fig. 2B, middle panel), whereas in the higher drug concentration $(10 \mu \mathrm{g} / \mathrm{ml})$, a clear $\mathrm{G} 1 / \mathrm{S}$ arrest was induced (G1-phase: from $\sim 48 \%$ in the control to $\sim 58 \%$ in the higher dose). As with RT4 cells, this was accompanied by an S-phase block (S-phase: from $\sim 27 \%$ in the control to $\sim 42 \%$ in the higher dose) (Fig. 2B, bottom panel).

Grade- and dose-dependent activation of apoptotic machinery in response to doxorubicin. In both RT4 and T24 cell lines, the initiator pro-Caspase- 8 and -9 , as well as the precursor of the major effector protease of apoptosis Caspase-3, were found to be cleaved specifically, after doxorubicin treatment in a dose-dependent fashion, as unambiguously evinced by the generation of their respective proteolytic fragments (17 and $19 \mathrm{kDa}$ for Caspase-3; 18, 41 and $43 \mathrm{kDa}$ for Caspase-8; 35 and $37 \mathrm{kDa}$ for Caspase-9) (Figs. 3A and 4A). Moreover, two characteristic substrates of the activated Caspase repertoire (namely, processed pro-Caspase-3, -6 and -7), PARP and 
(A) Doxorubicin $(\mu \mathrm{g} / \mathrm{ml})$ : $\quad-10$

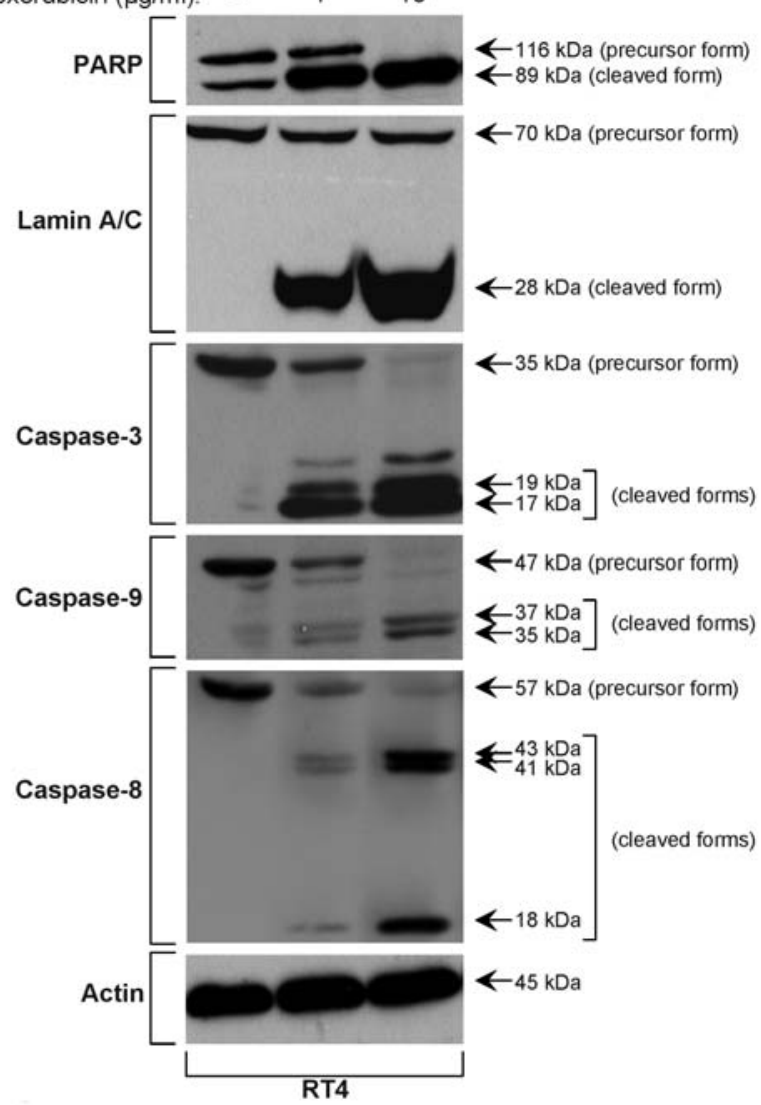

(B)

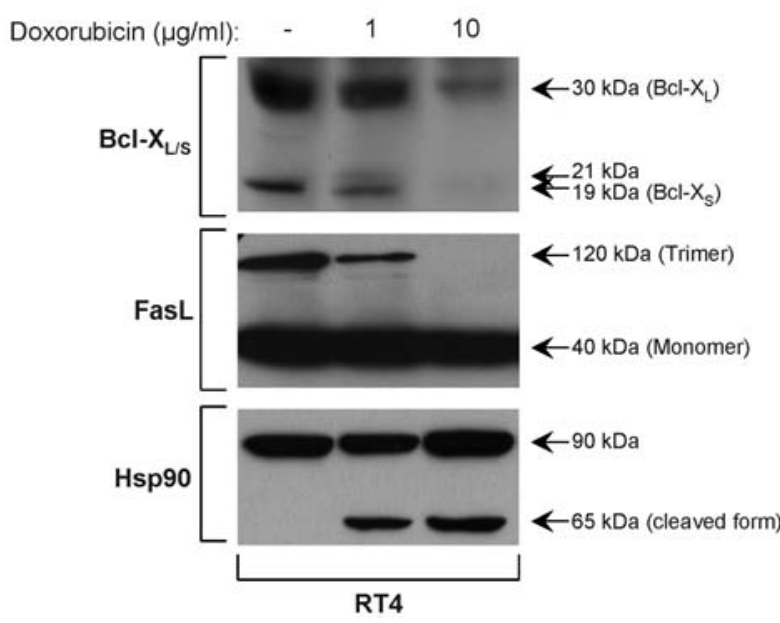

Figure 3. Expression and proteolytic processing of apoptosis-related proteins in response to 0,1 and $10 \mu \mathrm{g} / \mathrm{ml}$ doxorubicin for $24 \mathrm{~h}$ in RT4 bladder cancer cells. Pan-Actin was used as an internal control to identify equal amounts of protein loading in each lane. (A), The drug induced a dose-dependent cleavage of PARP, Lamin A/C, Caspase-3, Caspase-9 and Caspase-8, demonstrating that the cell death observed in doxorubicin-treated RT4 cells is due to apoptosis. (B), Doxorubicin induced a dose-dependent: a) proteolytic cleavage/ down-regulation of $\mathrm{Bcl}-\mathrm{X}_{\mathrm{L}}, \mathrm{b}$ ) decrease of the homotrimeric form of cytosolic FasL and c) proteolytic cleavage of Hsp90, likely due to Granzyme B activity. Data are from three different experiments, one of which is illustrated here.

Lamin $\mathrm{A} / \mathrm{C}$, both representing nuclear components tightly associated with the integrity of nuclear structure and function, were found to be specifically cleaved in a similar dosedependent manner, thus resulting in the formation of 89 and $28 \mathrm{kDa}$ proteolytic fragments, respectively (Figs. 3A and 4A).
(A)

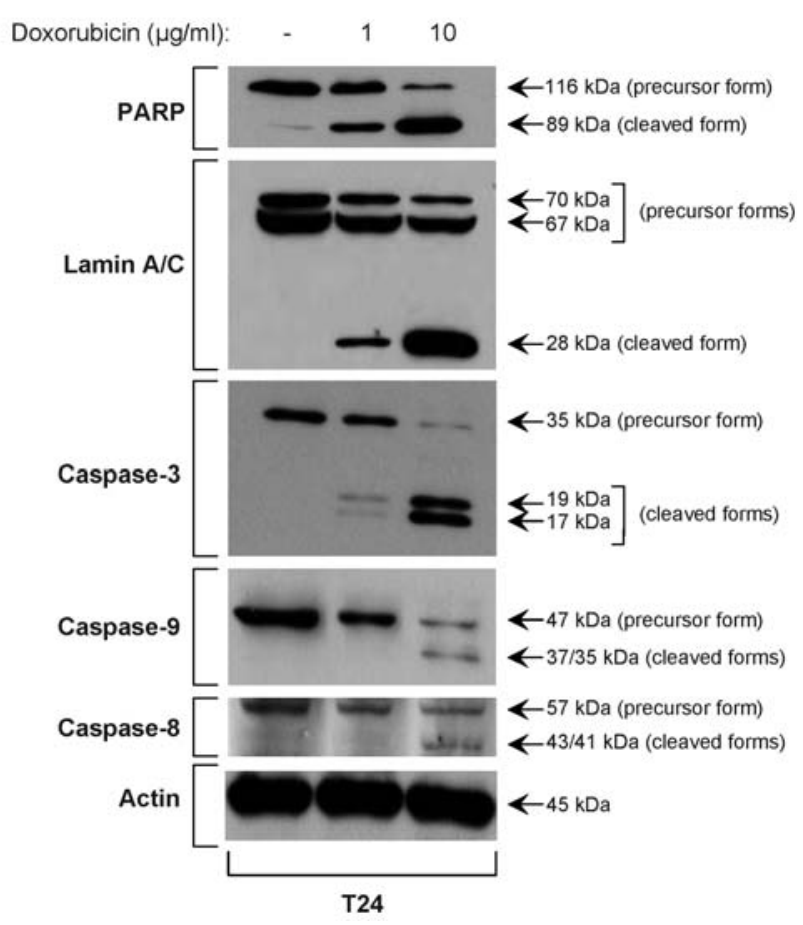

(B)

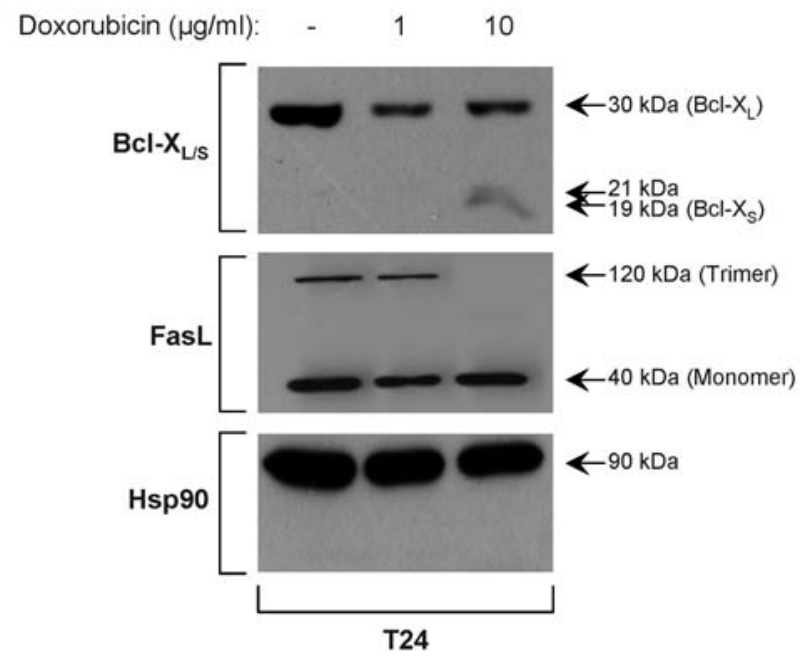

Figure 4. Expression and proteolytic processing of apoptosis-related proteins in response to 0,1 and $10 \mu \mathrm{g} / \mathrm{ml}$ doxorubicin for $24 \mathrm{~h}$ in T24 bladder cancer cells. Pan-Actin was used as an internal control to verify equal protein loading in each lane. (A), The drug induced a dose-dependent cleavage of PARP, Lamin A/C, Caspase-3, Caspase-9 and Caspase-8, proving that the cell death observed in doxorubicin-treated T24 cells is due to apoptosis. (B), Doxorubicin induced a dose-dependent: a) proteolytic cleavage/down-regulation of $\mathrm{Bcl}-\mathrm{X}_{\mathrm{L}}, \mathrm{b}$ ) decrease of the homotrimeric form of cytosolic FasL and, interestingly, c) absence of Hsp90 proteolytic cleavage. Comparing the data presented in Figs. 3 and 4, one can observe the unambiguous grade-dependent response to doxorubicin activity. Data are from three different experiments, one of which is illustrated here.

In RT4 cells, after treatment with the lower dose $(1 \mu \mathrm{g} / \mathrm{ml})$ of doxorubicin, we could observe a significant reduction in the uncleaved protein fraction of inactive (precursor) proCaspase-8, -9 and -3 (35 kDa for Caspase-3; $57 \mathrm{kDa}$ for Caspase-8; $47 \mathrm{kDa}$ for Caspase-9), as well as a slighter one for the Caspase repertoire characteristic substrates PARP and Lamin A/C (116 kDa precursor form for PARP; $70 \mathrm{kDa}$ for 
Lamin $\mathrm{A} / \mathrm{C}$ ), while one or more cleaved forms of the corresponding proteins were undoubtedly detected. In the higher dose $(10 \mu \mathrm{g} / \mathrm{ml})$ of doxorubicin, the uncleaved precursor proteins were in most cases almost absent, whereas the cleaved products were identified as bands of very high density, compared to the lower dose treatments (Fig. 3A). The obtained results were qualitatively similar in T24 cells, also exhibiting a dose-dependent proteolytic pattern. However, the extent of the cleavage of the respective precursor proteins and, most importantly, the ensuing generation of their cognate proteolytic fragments (even they both retain their dose-specific character), when compared to the RT4 respective events, were significantly diminished (or even obliterated) in all the examined cellular proteins, with Lamin A/C and Caspase-3 representing the most prominent examples especially in the lower drug concentration (Fig. 4A). These results strongly suggest that doxorubicin induces dose- and grade-dependent apoptotic death in human bladder cancer cell lines, with RT4 cells being more sensitive to doxorubicin-induced cleavage of target proteins than $\mathrm{T} 24$.

In RT4 cells, the inhibitor of apoptosis $\mathrm{Bcl}_{\mathrm{L}}(30 \mathrm{kDa})$ together with the pro-apoptotic short protein isoform $\mathrm{Bcl}-\mathrm{X}_{\mathrm{S}}$ (19 kDa) were observed to be down-regulated in a dosedependent manner after doxorubicin treatment (Fig. 3B). In $\mathrm{T} 24$ cells, Bcl- $\mathrm{X}_{\mathrm{L}}$ protein was similarly down-regulated in a dose-dependent fashion, whereas a faint band of the Bcl- $\mathrm{X}_{\mathrm{S}}$ isoform was observed only in the higher concentration of doxorubicin, fitting to the stronger malignancy potential of the T24 cells (Fig. 4B). These observations clearly indicate that doxorubicin-induced apoptosis in human bladder cancer cells is not only implemented by the activation of Caspase cascade, but also by the cleavage and regulated degradation of certain anti-apoptotic proteins, with $\mathrm{Bcl}^{-\mathrm{X}_{\mathrm{L}}}$ being one of the most characteristic examples.

According to its subcellular localization, the pro-apoptotic ligand FasL exists in two different forms: the transmembrane (mFasL) and the soluble (sFasL). In order to bind and activate its cognate Fas receptor, mFasL has to form tightly crosslinked trimeric species in the cytoplasm, from a cytosolic pool of inactive monomers, which then shuffle to the cell membrane, where they are appropriately assembled into functional double homotrimeric complexes $(23,24)$. In both RT4 and T24 cells, the monomeric form of FasL was observed as a protein band of $\sim 40 \mathrm{kDa}$, revealing an invariable dose-independent expression profile (Figs. 3B and 4B). Interestingly, in RT4 cell line, the homotrimeric form of FasL ( $120 \mathrm{kDa})$ was found to decrease in the doxorubicin dose of $1 \mu \mathrm{g} / \mathrm{ml}$ (Fig. 3B), whereas the lower-dose drug-treated T24 cells seem to retain unaffected the protein amount of FasL trimeric form (Fig. 4B), thus strongly indicating their relative resistance to apoptotic death under lower doses of doxorubicin treatment. On the contrary, as it is clearly demonstrated, for the first time, in Figs. 3B and $4 \mathrm{~B}$, in the presence of $10 \mu \mathrm{g} / \mathrm{ml}$ of doxorubicin, both cell types are characterized by a complete obliteration of the FasL cytosolic homotrimeric form likely shuffling to the cell membrane and thereby harmonically beseeming to their virulent apoptotic profile (25). The above findings reveal that during doxorubicin treatment the amount of cytosolic trimeric FasL is reduced in a dose- and grade-dependent fashion.
The molecular chaperone Hsp90 plays a significant role in the refolding of denatured proteins and the conformational maturation of nascent polypeptides into biologically active native molecules. Due to these molecular properties and to the multitude of its protein clients, relatively recently, Hsp90 has emerged as a promising target for cancer therapy (26-28). In the present study, we have examined the structural integrity of Hsp90 after different doses (1 and $10 \mu \mathrm{g} / \mathrm{ml})$ of doxorubicin treatment in human bladder cancer cells. In RT4 cells, Hsp90 chaperone $(\sim 90 \mathrm{kDa})$ was found to be specifically cleaved by both drug concentrations used, generating a proteolytic fragment of $\sim 65 \mathrm{kDa}$ (Fig. 3B). Interestingly, in T24 cells Hsp90 was found to be insensitive (complete absence of any detectable proteolytically processed form) to the same doxorubicin treatments (Fig. 4B). These novel data strongly dictate, for the first time, that Hsp90 is amenable to a gradedependent regulatory mechanism of doxorubicin-induced apoptotic proteolysis.

Expression analysis of genes involved in the regulation of cell cycle progression and apoptosis. In an effort to study and compare the biological responses of two human bladder cancer cell lines of differentiation grades I and III to doxorubicin and to possibly identify new biomarkers of grade-dependent response to the drug, we have analyzed expression at the mRNA level of 41 genes (Table I), through a semi-quantitative RT-PCR approach. The proteins encoded by these genes are critically involved in the regulation of fundamental cellular mechanisms, such as cell cycle and apoptosis.

To this end, we have first analyzed genes involved in the regulation of cell cycle. In RT4 cells treated with $1 \mu \mathrm{g} / \mathrm{ml}$ doxorubicin, the mRNA levels of Cyclin-E1, -E2 and $-D$, responsible for the G1/S checkpoint, remained constant (Fig. 5). In contrast, $C y c l i n-B 1,-B 2$ and $-F$, which regulate transition from G2- to M-phase (along with $p 21^{\text {Cipl }}$ and GADD45A) were down-regulated, whereas $p 21^{\text {Cipl }}$ and GADD45A were induced. When using $10 \mu \mathrm{g} / \mathrm{ml}$ of doxorubicin in RT4 cells, with the exception of $C y$ clin-D, the expression of the genes examined was down-regulated (Cyclin-E2 and Cyclin-B1) or completely suppressed (Cyclin-E1,Cyclin-B2, Cyclin-F, p21 Cipl and GADD45A) (Fig. 5). These results are in accord with our findings from the cell cycle analysis experiments (Fig. 2), in which the lower concentration of doxorubicin blocked RT4 cells in G2/M-phase, whereas the higher concentration of the drug rather induced a G1/S arrest together with an S-phase block.

In T24 cells, the expression profile of the above genes to doxorubicin did not vary significantly, albeit a few distinct differences could be undoubtedly detected. In the lower doxorubicin concentration, Cyclin-El was found to be upregulated, while $C y c l i n-E 2$ and $-D$ retained invariable expression levels. At the same time, $C y c l i n-B 1,-B 2$ and $-F$, together with $p 21^{\text {Cip } 1}$ and $G A D D 45 A$ were all down-regulated. When T24 cells were treated with $10 \mu \mathrm{g} / \mathrm{ml}$ of doxorubicin, the expression levels of Cyclin-E1, $-E 2$ and $-F$, along with $p 21^{C i p l}$ and GADD45A were down-regulated, whereas the levels of Cyclin-B1, $-B 2$ and $-D$ remained unaffected (Fig. 5). These results in T24 largely agree with our observations from the experiments on cell cycle analysis (Fig. 2), where the lower concentration of doxorubicin induced a G2/M-phase inhibition accompanied 


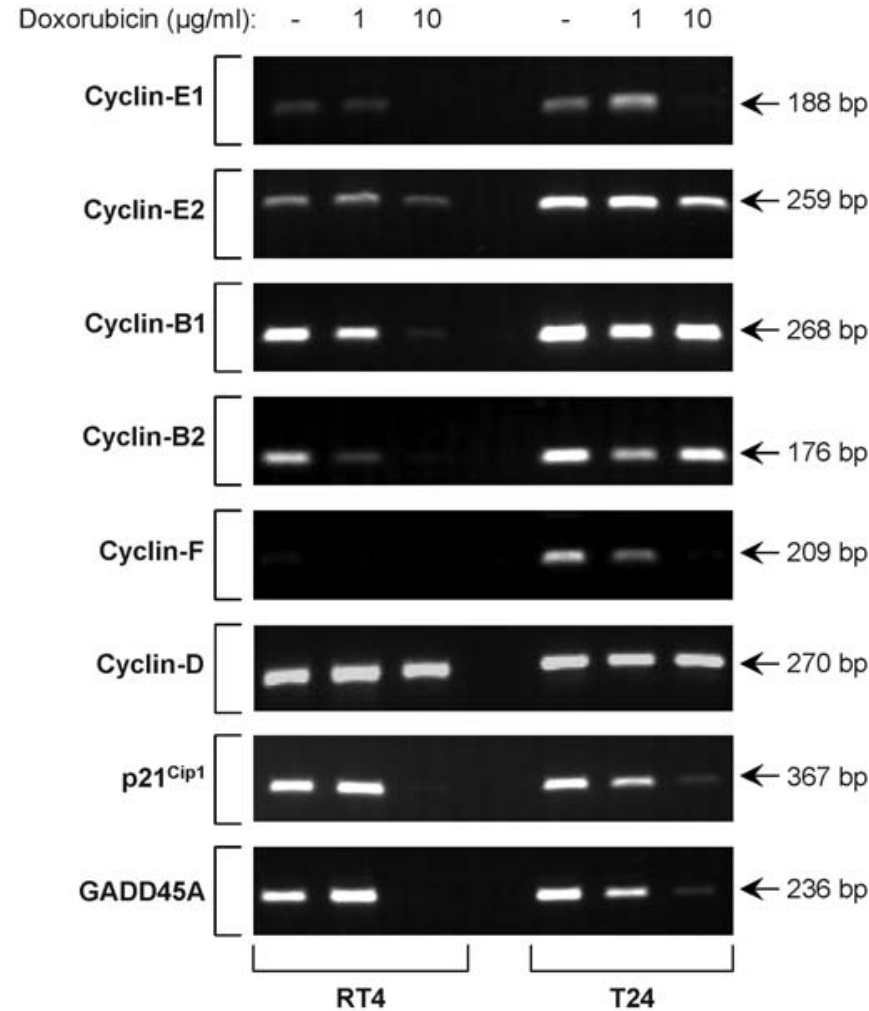

Figure 5. Expression analysis of genes involved in the regulation of cell cycle after treatment with 0,1 and $10 \mu \mathrm{g} / \mathrm{ml}$ doxorubicin for $24 \mathrm{~h}$ in the human urinary bladder cancer cell lines RT4 and T24, through a semi-quantitative RTPCR approach. The genes are indicated on the left and the respective RT-PCR product sizes on the right. Data are from three different experiments, one of which is shown here.

by an S-phase block. On the contrary, the higher concentration of the drug induced a G1/S arrest together with an S-phase block. All the above data strongly support the notion that cell cycle arrest at different checkpoints induced by doxorubicin is controlled by an individualized combinational network of regulatory molecules, with a few of them likely bearing a master biological role, whereas the rest retain minor or redundant activities. For example, even though the G2/Mphase arrest induced in the lower-dose doxorubicin-treated RT4 cells is likely implemented, among others, through downregulation of $C y c l i n-B 1,-B 2$ and $-F$, along with an upregulation of $p 21^{C i p l}$ and $G A D D 45 A$ gene expression, the respective T24 response (lower-dose drug-mediated G2/M-phase arrest and $\mathrm{S}$-phase block) is characterized by a qualitatively similar Cyclin gene expression profile, albeit accompanied by downregulation of $p 21^{C i p l}$ and GADD45A gene activities. Therefore, it is rather the relative quantitative differences among the various signaling components that may play a critical role in the final cellular response.

Next, we have analyzed the expression pattern of $p 53$ and related genes $p 63$ and $p 73$ before and after doxorubicin treatment. In lower concentrations of drugs inducing DNA damage, wild-type $p 53$ is known to play a critical role in cell cycle arrest, whereas in higher drug concentrations it preferentially causes apoptosis. In RT4 cells, characterized by a wild-type $p 53$ genetic locus, the lower doxorubicin concentration induced $p 53$ and $p 73$ gene expression, whereas downregulation of $p 63$ was clearly detected (Fig. 6). This could

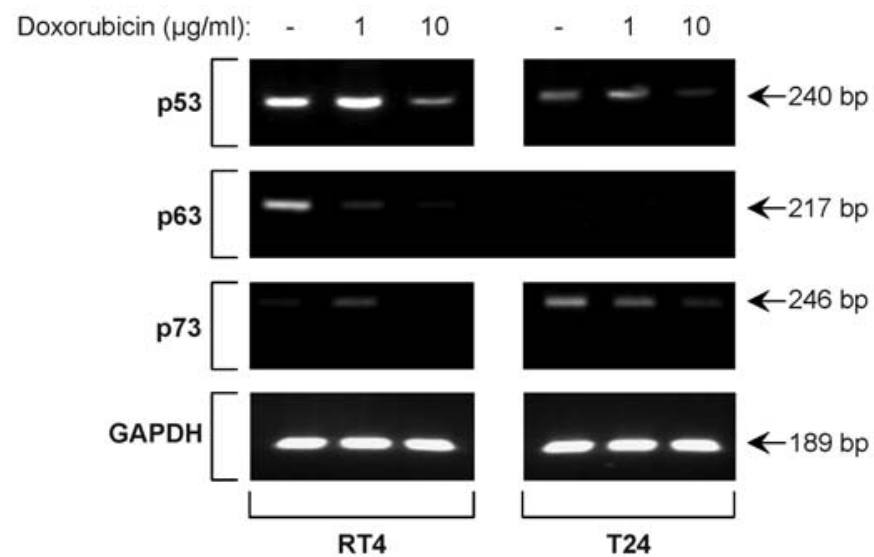

Figure 6. Expression patterns of p53 family genes, along with the housekeeping gene $G A P D H$, used for normalization of the results, after treatment with 0,1 and $10 \mu \mathrm{g} / \mathrm{ml}$ doxorubicin for $24 \mathrm{~h}$ in the human urinary bladder cancer cell lines RT4 and T24, using semi-quantitative RT-PCR. The examined genes are indicated on the left and the respective RT-PCR product sizes on the right. Data are from three different experiments, one of which is presented here.

possibly be one of the mechanisms promoting the drug-induced G2/M arrest observed in these cells (Fig. 2). In T24 cells carrying a mutant $p 53$ gene (an in-frame deletion in exon 5), p53 expression was slightly upregulated in the lower concentration of the drug, whereas $p 73$ was down-regulated. Interestingly, in these cells, $p 63$ could not be detectably expressed either before or after drug treatment (Fig. 6). It is likely that a genetic and/or epigenetic profile comprised by a mutant $p 53$, a silenced or absent $p 63$ and a down-regulated $p 73$ could partly account for the reduced sensitivity of T24 cells to the lower concentration of doxorubicin treatment (Figs. 1, 3 and 4). In the higher concentration of the drug, in both cell lines, gene expression was down-regulated (RT4: p53 and p63; T24: p53 and $p 73$ ) or obliterated (RT4: p73) (Fig. 6). This could be possibly attributed to a doxorubicin-mediated reduction in negative superhelicity of the DNA molecule at specific genetic loci, leading to disturbance of the distribution and transmission of torsional strain and finally resulting in a chromatin topologydependent decrease of gene transcription activity $(29,30)$. Similar obstructive mechanisms could likely apply to several genes examined in the present study.

Successful triggering of apoptosis is a critical step in cancer chemotherapy $(31,32)$. Therefore, understanding the molecular events related to apoptosis, which literally underlie druginduced cellular response, is important in enabling a more rational approach to grade-dependent strategies concerning anticancer therapy, based on the detection of novel putative biomarkers of response to drug treatment $(33,34)$. Thus, in order to study the response to doxorubicin activity we have analyzed the expression profile of a number of genes essentially involved in the regulation of apoptosis (35).

The expression pattern of the genes selected for the study of apoptotic process in response to doxorubicin treatment is shown in Figs. 7-11. In these results, first, we observe that the genes Tweak (Fig. 8) and Bok (Fig. 10) are hardly expressed and $O P G$ (Fig. 9) is completely suppressed in RT4 cells, whereas their expression levels are easily detectable in T24 cells. Exactly the opposite scenario is true for the gene 


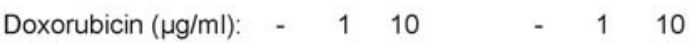
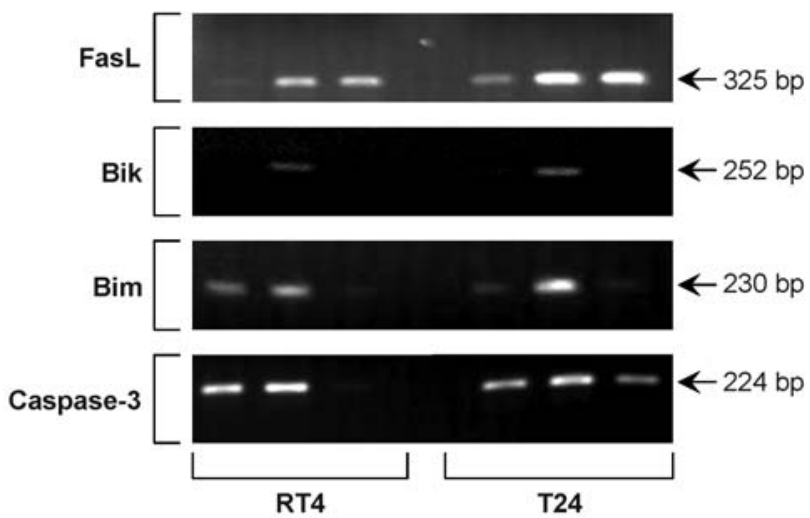

Figure 7. Expression profiles of genes involved in the regulation of apoptosis after treatment with 0,1 and $10 \mu \mathrm{g} / \mathrm{ml}$ doxorubicin for $24 \mathrm{~h}$ in the human urinary bladder cancer cell lines RT4 and T24, using a semi-quantitative RT-PCR approach. These genes were found to exhibit a grade-independent pro-apoptotic response to the drug. The genes are indicated on the left and the respective RT-PCR product sizes on the right. Data are from three different experiments, one of which is illustrated here.

encoding for TRAIL (Fig. 8). Second, the vast majority of genes, with a few distinct exceptions, such as FasL (RT4 and T24; Fig. 7), Tweak (RT4; Fig. 8), Noxa (RT4 and T24; Fig. 8), Survivin (T24; Fig. 9) and Bid (T24; Fig. 10), are downregulated in the higher concentration of doxorubicin. Third, according to their response to doxorubicin, these genes could be classified into three major groups: a) the genes that exhibited a grade-independent pro-apoptotic response (Fig. 7), b) the genes that showed a grade-dependent proapoptotic response (Figs. 8 and 9) and c) the genes that manifested a grade-specific (in most cases) but 'unexpected' (opposite to the 'predicted') drug response and/or expression profile. These were arbitrarily named 'compensatory' genes and likely represent a 'counterbalancing' and/or 'defense' mechanism against the cytotoxic effects of doxorubicin treatment (Fig. 10).

Among the genes examined in the present study, the genes that are characterized by a grade-independent pro-apoptotic response to doxorubicin are only four. Namely, these are FasL, Bik, Bim and Caspase-3. FasL and Bik are significantly induced in both RT4 and T24 bladder cancer cell lines after the lower-dose doxorubicin treatment, whereas Bim and Caspase-3 seem to be more moderately upregulated. On the contrary, with the exception of FasL, which retains strong and unimpaired expression levels, under the higher dose of doxorubicin conditions Bim and Caspase-3 are notably downregulated, while Bik expression is most severely affected (completely suppressed) in both cell types (Fig. 7). Interestingly, the significant upregulation of FasL gene expression might be directly associated with the drug-induced apoptotic death of RT4 and T24 cell lines, as the latter is undoubtedly evinced through the activation of Caspase repertoire and proteolytic cleavage of its target substrates, demonstrated in Figs. 3 and 4.

In the second group, showing a grade-dependent proapoptotic response to doxorubicin, the largest number of genes is included. Among these, we can spot the genes coding for the pro-apoptotic ligands TRAIL and Tweak, the death receptors

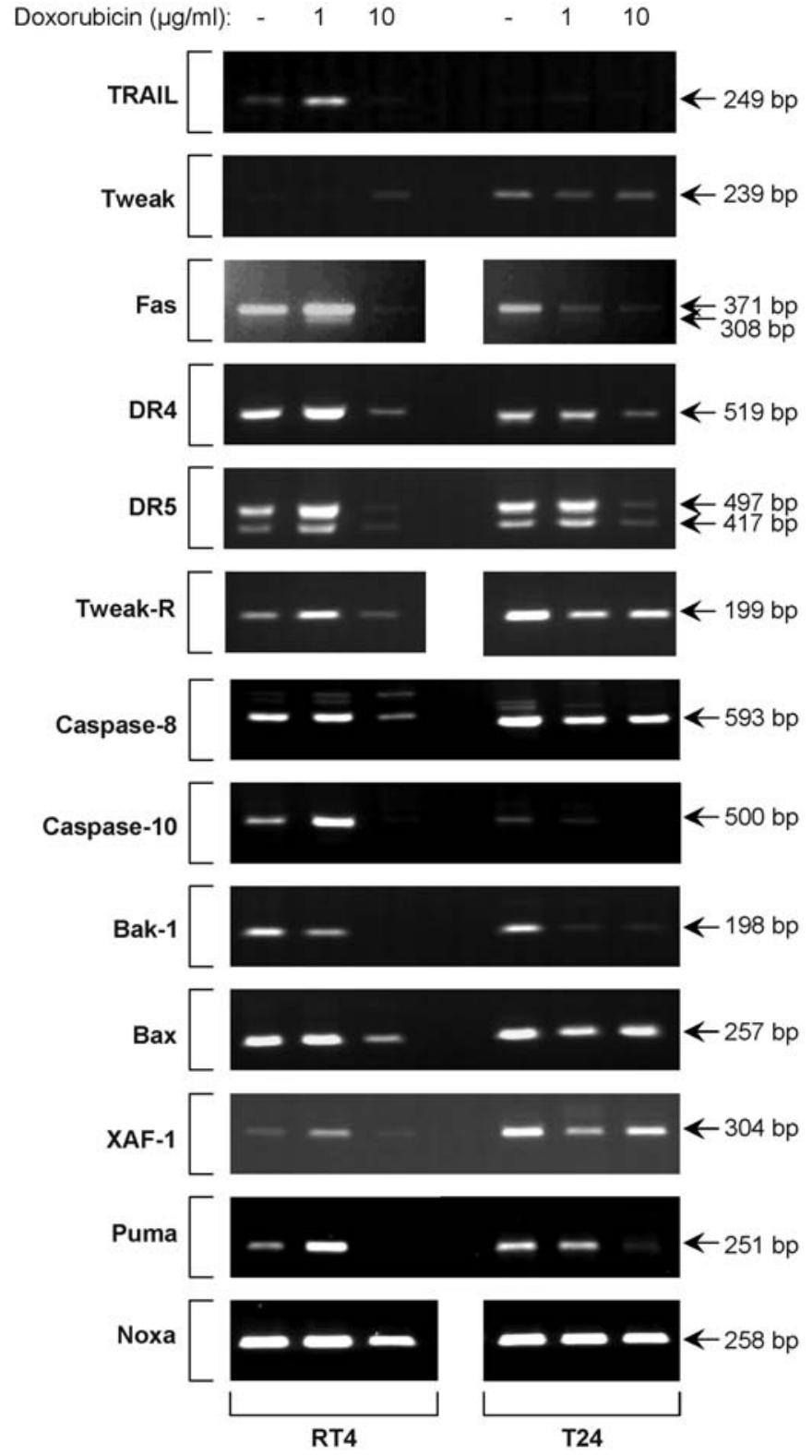

Figure 8. Expression analysis of genes involved in the regulation of apoptosis after treatment with 0,1 and $10 \mu \mathrm{g} / \mathrm{ml}$ doxorubicin for $24 \mathrm{~h}$ in the human urinary bladder cancer cell lines RT4 and T24, using semi-quantitative RT-PCR. These genes were characterized by a grade-dependent pro-apoptotic response to the drug. The genes are indicated on the left and the respective RT-PCR product sizes on the right. Data are from three different experiments, one of which is shown here.

Fas, DR4, DR5 and Tweak-R, the proteases Caspase- 8 and Caspase-10, as well as the genes coding for the pro-apoptotic mitochondrial pathway proteins Bak-1, Bax, XAF-1, Puma and Noxa. In RT4 cells, most of these genes (TRAIL, Fas, DR4, DR5, Tweak-R, Caspase-8, Caspase-10, XAF-1 and Puma) are upregulated in response to the lower doxorubicin concentration, whereas their expression is down-regulated or obliterated (Puma) in response to the higher-dose doxorubicin treatment (Fig. 8). Nevertheless, there are exceptions including Tweak, $B a k-1, B a x$ and Noxa, where in the lower doxorubicin concentration the transcript levels of $B a k-1$ are moderately reduced, while Bax and Noxa retain their strong expression. In the higher dose of doxorubicin, Noxa is the only unaffected gene, whereas Bak-1 and Bax are down-regulated or completely 

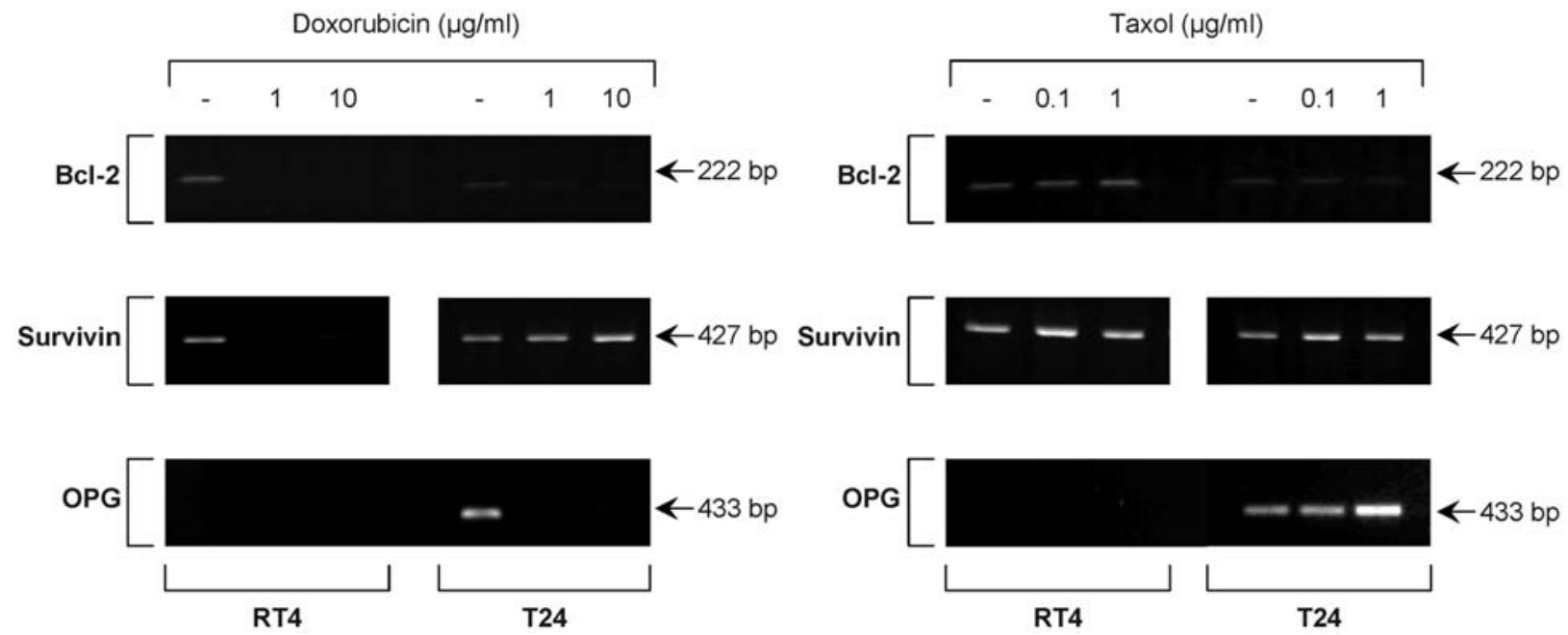

Figure 9. Expression analysis of genes involved in the regulation of apoptosis after treatment with 0,1 and $10 \mu \mathrm{g} / \mathrm{ml}$ doxorubicin (left panel) or $0,0.1$ and $1 \mu \mathrm{g} / \mathrm{ml}$ taxol (right panel) for $24 \mathrm{~h}$ in the human urinary bladder cancer cell lines RT4 and T24, using a semi-quantitative RT-PCR approach. These genes, along with others, were found to exhibit a grade- and drug-dependent pattern of expression, which renders them suitable to be used as biomarkers for the prognosis as well as for the response to doxorubicin activity during chemotherapy of human bladder cancer. The genes are indicated on the left and the respective RT-PCR product sizes on the right of each panel. Data are from three different experiments, one of which is illustrated here.

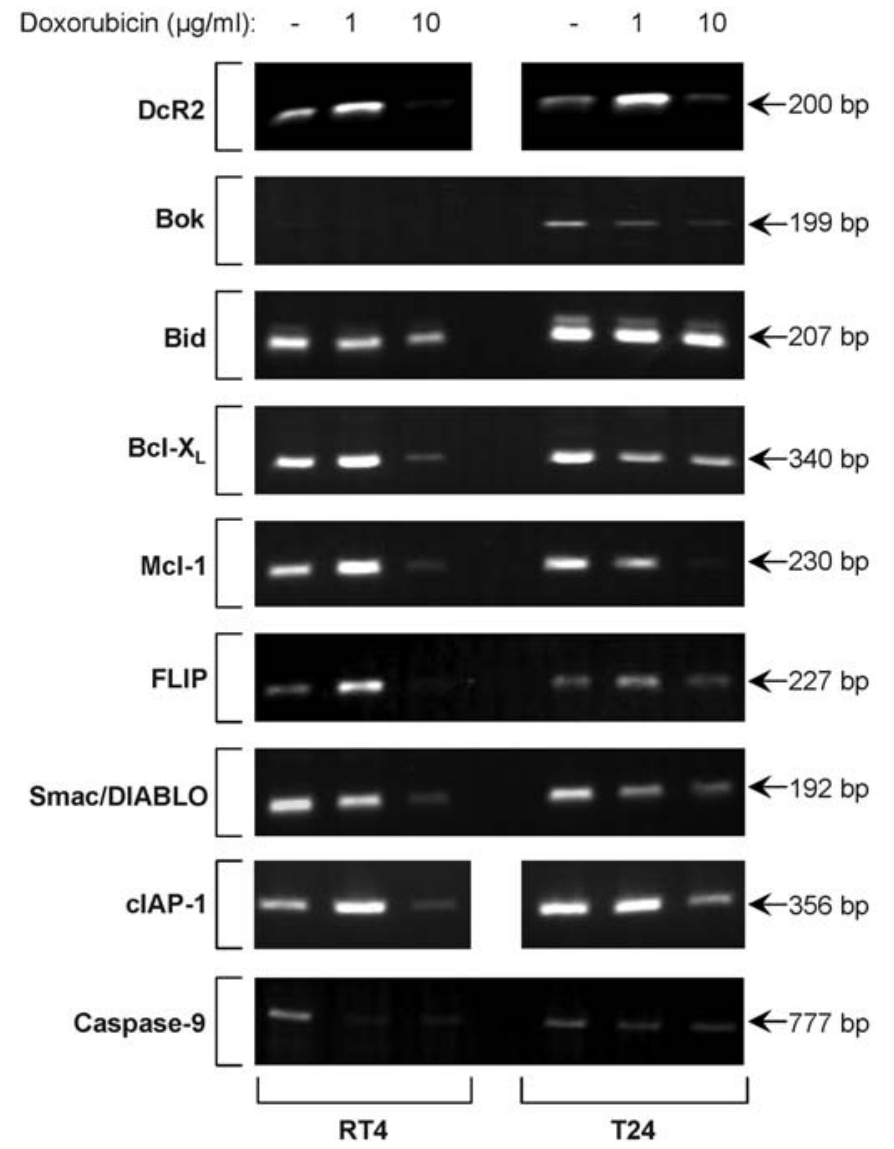

Figure 10. Expression analysis of genes involved in the regulation of apoptosis after treatment with 0,1 and $10 \mu \mathrm{g} / \mathrm{ml}$ doxorubicin for $24 \mathrm{~h}$ in the human urinary bladder cancer cell lines RT4 and T24, using semi-quantitative RTPCR. These genes were found to manifest a grade-dependent (in most cases) 'compensatory' response to the drug. The genes are indicated on the left and the respective RT-PCR product sizes on the right. Data are from three different experiments, one of which is shown here.

suppressed (Bak-1), and interestingly, Tweak is the only gene notably induced (Fig. 8).
On the other hand, in T24 cells under the lower drug concentration, several genes are down-regulated (Tweak, Fas, DR4, Tweak-R, Caspase-8, Caspase-10, Bak-1, Bax, XAF-1 and Puma), whereas only Noxa retains its invariable expression profile. On the contrary, TRAIL seems to be detectably induced, while DR5 exhibits a slight elevation of its expression levels (Fig. 8). The obtained gene activity profile in the higher drug dose is characterized by a notable, albeit variegated among the members of this group, reduction of expression of all genes, with Noxa being the only distinct exception (Fig. 8). The comparative gene expression patterns between RT4 and T24 human bladder cancer cells clearly corroborate their differential sensitivity to drug-induced apoptotic death, with T24 being significantly more resistant to the apoptotic stimulus (doxorubicin) than RT4. For example, the combination of pharmacogenomic responses of Fas, Caspase-10 and Puma could likely account, among others, for the differential sensitivity of RT4 and T24 to the lower dose of doxorubicin treatment (Figs. 1, 3, 4 and 8).

Belonging to the same group, the genes Bcl-2, Survivin and $O P G$ exhibited a very interesting expression pattern in response to doxorubicin, clearly reflecting the different state of malignancy of the two cell lines (Fig. 9). In RT4 cells, after doxorubicin treatment, expression of Bcl-2 and Survivin was severely suppressed, whereas $O P G$ was not expressed at all. On the contrary, in T24 cells in response to doxorubicin, $\mathrm{Bcl}-2$ was only partly down-regulated, whereas Survivin was not only unaffected in the lower drug dose, but also notably induced in the higher doxorubicin concentration. In the same cells, the expression of $O P G$ gene was completely obliterated under both drug dose conditions. At this point, it is very interesting to note the specificity of cellular response by comparing the expression patterns of $\mathrm{Bcl}-2$, Survivin and $O P G$ genes in RT4 and T24 bladder cancer cells in response to the topoisomerase II poison doxorubicin and the microtubule depolymerization inhibitor taxol, both used in anticancer therapy (Fig. 9). We can clearly observe that after taxol treatment $\mathrm{Bcl}-2$ expression remains almost unaffected in both 


Expression levels
\begin{tabular}{|r|l|}
\hline $0-5:$ & \\
\hline $6-15:$ & \\
\hline $16-30:$ \\
\hline $31-40:$ \\
\hline $41-55:$ & \\
\hline $56-75:$ & \\
\hline $76-95:$ & \\
\hline $96-115:$ \\
\hline $116-150:$ \\
\hline
\end{tabular}

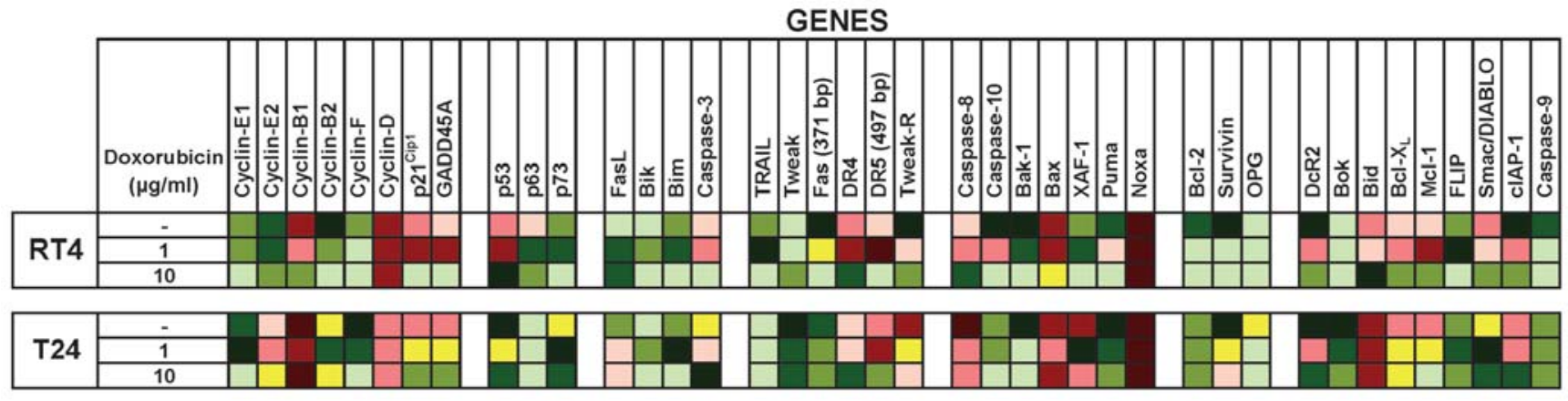

Figure 11. Integrated presentation of expression profiles of all the genes included in the present study, arbitrarily named 'mini-microarray'. This was constructed using the color code shown on top of the figure that corresponds to the intensities of individual bands obtained using semi-quantitative RT-PCR expression analysis. The development of handy 'mini-microarray' tools could prove to be very useful in the prognosis as well as in the response to specific drugs, and finally to a more efficient therapeutic management of the disease.

cell lines, Survivin transcript levels are slightly upregulated in the lower taxol concentration and then (higher drug dose conditions) they reach the control levels in both cell lines, whereas the grade-dependent (T24) OPG expression is notably upregulated in the higher taxol concentration (one could undoubtedly notice the reverse $O P G$ expression profile between doxorubicin- and taxol-treated T24 cells). It is important to denote that the same taxol concentrations (clinically and cytotoxically equivalent to the doxorubicin ones used in the present study), when applied to RT4 and T24 cells for $24 \mathrm{~h}$, induce apoptotic death (similar to the one resulting by doxorubicin treatment), as evinced by the taxol-dependent activation of Caspase repertoire and subsequent proteolytic cleavage of its target substrates (data not shown). These results may constitute a kind of reliable drug signature in human urinary bladder cancer cells.

The third group of genes is mainly characterized by a gradedependent (in most cases) and 'compensatory' response to doxorubicin-induced cytotoxic effects (Fig. 10). In RT4 cells, the anti-apoptotic genes $B c l-X_{L}, M c l-1, F L I P$ and $c I A P-1$, in the lower dose drug conditions, manifest an upregulation of their expression levels opposite to the predictable scenario, whereas the same genes are notably down-regulated $\left(B c l-X_{L}\right.$ and $M c l-1$ ), unaffected (cIAP-1) or slightly induced (FLIP) under identical treatment conditions in T24 cells. Surprisingly, the gene for the anti-apoptotic decoy receptor DcR2 is shown to be notably induced in the lower doxorubicin concentration in both cell lines. On the contrary, Caspase-9 gene exhibits RT4-specific suppression after drug treatment, whereas its expression in T24 remains almost unaffected. Moreover, the pro-apoptotic gene encoding for the inhibitor of cIAPs Smac/
DIABLO is, unexpectedly, down-regulated in a dosedependent fashion in both cell types. Regarding RT4, cIAP-2 and XIAP do not seem to play an essential role in this likely 'compensatory' response, since both genes remain unaffected in lower drug dose conditions. However, the notable reduction of $C I A P-2$ and XIAP expression levels indicate their potential involvement in this putative mechanism for T24 cells (data not shown). As expected from previous observations (Fig. 8), in the higher doxorubicin concentration, almost all the above genes are significantly suppressed in both cell lines, albeit in a variable fashion. Intriguingly, another two of the novel findings of the present study represent the grade-specific regulation (strongly expressed in T24 compared to RT4) of Bok gene and the robust transcriptional activity of Bid gene in T24 cells, compared to RT4 (with or without drug), features that could likely contribute to the herein proposed 'compensatory' cellular response after different doses of doxorubicin treatment (Fig. 10).

Conclusively, the genes Bok and $O P G$, which are specifically expressed in the grade III human bladder cancer cell line T24, along with the pro-apoptotic gene TRAIL, the expression of which is severely suppressed in the same cells, are of obvious importance for use in human bladder cancer prognosis and the choice of appropriate treatment for a more efficient disease management. Moreover, the large number of genes involved in cell cycle regulation and apoptosis, which are differentially expressed after doxorubicin treatment in grade I and grade III bladder cancer cells, seem good candidates to be adopted as biomarkers of response to doxorubicin treatment. It would be worthwhile, the expression of these genes to be analyzed in a clinical setting, as it could prove appropriate to 
be used in order to assess grade-specific differential responses to doxorubicin in the clinical practice.

Finally, in an effort to more conveniently apprehend and evaluate the grade- and drug-dependent gene expression profiles of the two bladder cancer cell lines examined here, all the obtained RT-PCR bands (as presented after separation in agarose gel electrophoresis; Figs. 5-10) were appropriately scanned and their respective intensities, after being measured via the Band Leader Application Version 3.00 (Magnitec, Tel-Aviv, Israel), were converted to a color code, with each color representing a different range of the transcript expression values (Fig. 11). The development of such a handy 'mini-microarray' tool could prove to be very useful in the prognosis as well as the more efficient therapeutic management of the disease.

\section{Discussion}

As in most cancers, the management of urothelial bladder cancer is highly dependent on tumor stage and grade. Patients with pTa (superficial, non-invasive) tumors most often undergo transurethral resection of the bladder tumor and receive rather mild intravesical therapy, whereas patients with pT2 (muscleinvasive) tumors undergo total cystectomy with more aggressive pre- and/or post-operative chemotherapy. On the other hand, depending on their molecular background, pT1 (chorioninvasive) tumors may be treated either as pTa or as pT2 $(1,3)$. For the treatment of invasive tumors of the bladder, a variety of pre- and post-operative chemotherapy regimens have evolved, with doxorubicin being one of the drugs frequently used in combination therapy for this type of disease $(9,10)$.

Doxorubicin belongs to the anthracycline class of antibiotics that targets and functionally inhibits topoisomerase II and has been auspiciously adopted and used as an antitumor drug in cancer chemotherapy for several years $(6,8)$. And while the variety of its modes of action as well as its immediately obvious powerful effects are rather well documented, nevertheless, the dose-dependent thresholds for these mechanisms and their related implications in fundamental biological functions still remain obscure $(18,19,36)$. In the present study, we have examined the effects of doxorubicin on important cellular processes, such as the regulation of cell cycle and apoptosis, also seeking to possibly identify new biomarkers directly associated with the reliable monitoring of gradedependent response to doxorubicin treatment in human urinary bladder cancer cells.

The data presented herein demonstrate that the bladder cancer cell lines RT4 (grade I) and T24 (grade III) are both sensitive to doxorubicin treatment, with T24 being significantly more resistant to drug-induced apoptotic cell death than RT4. In both cell lines, it seems that cell death was preceded by a $\mathrm{G} 2 / \mathrm{M}$ arrest induced by the lower dose $(1 \mu \mathrm{g} / \mathrm{ml})$ of doxorubicin or a combination of G1/S- and S-phase block triggered by the higher dose $(10 \mu \mathrm{g} / \mathrm{ml})$ of the drug (Fig. 2). Therefore, we have studied the expression of the Cyclin-E1, $-E 2,-D$, $-B 1,-B 2$ and $-F$ genes, involved in cell cycle regulation, as well as $p 21^{\text {Cipl }}$, encoding for a bona fide cell cycle inhibitor and representing a p53 target gene, and GADD45A gene, a second p53 target critically involved in DNA repair, in order to analyze their regulation patterns in response to doxorubicin. $C y c l i n-B$ and $-E$ have been shown to predict relapse in patients with node-negative breast cancer (37), to associate with a significantly shorter survival time in stage I NSCLC (38), to be overexpressed in malignant breast tumors (39), to have a positively correlated expression with occult cervical lymph node metastasis in tongue carcinoma (40), to be amplified in $15-20 \%$ of gastric cancers (41) and finally to associate their overexpression with aggressiveness of the disease and poor clinical outcome independent of the tumor stage in many human cancers (42-44). Additionally, Cyclin-B1 expression closely correlated with the Ki-67 labeling index and both Cyclin-B1-associated G2/M arrest and Rb-mediated G1 arrest were found to be consistently compromised in high-grade pulmonary neuroendocrine tumors (45). Moreover, $p 21^{\text {Cip } 1}$ expression was shown to be lower in malignant breast tumors than in benign breast pathology (39), loss of expression of $p 21^{\text {Cip } 1}$ and/or upregulation of $C y c l i n-B 1$ and $-E$ proved to predict poor prognosis after surgery in stage I NSCLC (38), while the expression levels of Cyclin-E were significantly higher and GADD45A protein expression was decreased in the malignant than in the borderline epithelial ovarian tumors, meaning that these proteins are involved in the progression from borderline to malignant tumor of the ovaries (46). In our cell system, in accordance to the above, Cyclin-B, $-E$ and $-F$ were found to be expressed at a higher level in T24 than in RT4 human bladder cancer cell line.

In response to doxorubicin treatment, A549 cells exhibited an upregulation of $p 21^{C i p l}$, Bax and GADD45A, with repression of $C y c l i n-B 1$ mRNA and protein expression (47). Interestingly, $C y c l i n-B$ levels were strongly elevated in doxorubicin-treated MDA-MB-231 cells, whereas minimal changes in $C y c l i n-B$ levels were observed in MCF-7 cells treated with the same drug (48). On the other hand, Cyclin-B1 protein expression remained constant and was not followed by a G2/M arrest in three doxorubicin-resistant gastric cancer cell lines, whereas in their corresponding parent cell lines Cyclin-B1 reduction was followed by a clear G2/M arrest (49). In this study, in RT4 cells, treatment with the lower dose of doxorubicin resulted in down-regulation of $C y c l i n-B 1,-B 2$ and $-F$, upregulation of p53, p21 $1^{\text {Cipl }}$ and GADD45A, and constant expression levels of Cyclin-E1, -E2 and -D (Figs. 5 and 6). In T24 cells, although $p 21^{\text {Cipl }}$ and $G A D D 45 A$ were notably down-regulated after lower dose of doxorubicin treatment, compared to RT4 cells (presumably a T24-specific 'escape' mode to doxorubicin cytotoxic activity), most likely due to the presence of a mutant p53 gene harbored in this cell line (50), the observed G2/M arrest could be eventually attributed to the moderate suppression of Cyclin-B1 and significant down-regulation of $C y c l i n-B 2$ and $-F$. On the other hand, the combination of G1/S- and S-phase arrest observed in both cell lines, when using the higher dose of doxorubicin, was associated with down-regulation or obliteration of Cyclin-E1, -E2 and $-F$ gene expression, while transcript levels of $C y c l i n-B 1$ and $-B 2$ exhibited grade-dependent characters, being severely attenuated in RT4, while remaining almost unaffected in T24 cells (Fig. 5). From these results, we can safely conclude that, in this cell model: a) Cyclin-D does not seem to play a critical role in the regulation of cell cycle progression after doxorubicin treatment; b) Cyclin- $F$ appears to be essentially involved in all drug-induced cell cycle blocks (G1/S, S and G2/M), thus putatively occupying a central position in the complicated 
network controlling cell cycle progression; c) Cyclin-E family members seem to be tightly associated with G1/S- and Sphase blocks; d) the G2/M-phase arrest is likely implemented in a grade-independent fashion through down-regulation of $C y c l i n-B 1,-B 2$ and $-F$ [albeit a few quantitative differences between the two cell types can be observed (i.e. Cyclin-F)]; e) the grade-specific drug response of $p 21^{\text {Cipl }}$ and GADD45A, namely upregulated in RT4-treated cells with $1 \mu \mathrm{g} / \mathrm{ml}$ of doxorubicin and down-regulated in T24 cells under similar drug dose conditions, clearly reflects the complicated mode and combinational fashion of mammalian cell response to the cytotoxic actions of chemotherapeutic drugs. An integrated cellular reaction to a detrimental reagent likely embraces cell type-specific 'relinquish' mechanisms (i.e. cell cycle arrest and apoptosis), which could be partly 'compensated' by potent 'escape' and/or 'defense' mechanisms (i.e. T24-specific $p 21^{\text {Cip } 1}$ and $G A D D 45 A$ down-regulation; Fig. 10), in an effort to maintain cellular homeostasis and survival.

The two human urinary bladder cancer cell lines used in this study are characterized by distinct marked differences in terms of their genetic background. RT4 cells possess wild-type $p 53$ and $R b$ genes, whereas they do not exhibit any detectable $\mathrm{Rb}$ protein expression and harbor a homozygous $I N K 4 \mathrm{~A} / \mathrm{p} 16$ deletion (51). When p53 is overexpressed, the cell cycle is severely perturbed and blocked at both G1/S and G2/M checkpoints, while a transient S-phase block might also be observed (52). In wild-type p53 cells, inhibition of topoisomerase II can induce $\mathrm{G} 1$ cell cycle arrest by $p 53$ upregulation, followed by transcriptional induction of $p 21^{\text {Cipl }}$ gene expression (36). This G1 checkpoint was found to be tightly regulated by the ATM/ATR signaling network, through Chk1/Chk2 stress kinase functions at lower drug doses of doxorubicin, whereas, at higher doses, p53-dependent apoptosis mainly implemented through Fas, Puma and Bax upregulation was previously shown to occur (20). Aside from the G1 block, a distinct arrest in $\mathrm{G} 2$ has been also reported to result as a major cytotoxic response to doxorubicin. In wild-type $p 53$ cells, the G2 checkpoint was shown to function in an ATM-independent fashion, while it appeared to be strongly associated with inhibition of histone $\mathrm{H} 3$ phosphorylation, induced through inhibitory phosphorylation of Cdc2 kinase at lower drug doses, as well as with Cyclin-B1 down-regulation at higher doses of doxorubicin $(20,21)$.

Opposite to RT4, T24 cells possess a wild-type $R b$ gene and normal levels of $\mathrm{Rb}$ protein expression, whereas they harbor a mutant $p 53$ gene [an in frame TAC deletion in exon 5, resulting in the absence of critical tyrosine $\left.126\left(\mathrm{Y}^{126}\right)\right]$, and a methylated INK4A/pl6 genetic locus $(50,51)$. While the loss of a functional p53 protein can eliminate $\mathrm{G} 1$ block in response to DNA damage, such cells may still arrest rapidly in G2 (52). Interestingly, DNA damage-induced G2 arrest can be abrogated by caffeine, an ATM/ATR inhibitor. This indicates that p53-independent pathways, such as the ATM/ATR-Chk1/ Chk2-Cdc25-14-3-3sigma-CDK1 pathway, may also play an important role in $\mathrm{G} 2$ arrest at lower doses of doxorubicin, whereas at higher doses, apoptosis is triggered by the ATM/ ATR-Chk1/Chk2 backup system with subsequent E2F1 activation and $p 73$ upregulation, followed by transcription of Bax, Puma and Noxa genes, ultimately leading to apoptosis $(20,21)$.
As it is demonstrated in the present study (Fig. 6), expression of p53 at the mRNA level in RT4 cells was induced after treatment with the lower doxorubicin concentration, and then, significantly repressed in response to the higher dose of the drug. A similar pattern of expression was observed for p73 gene family member, whereas p63 was notably downregulated in response to doxorubicin in a dose-dependent fashion (Fig. 6). The obtained expression pattern of $p 53$ is in absolute accordance with the $p 21^{C i p l}$ and $G A D D 45 A$ respective ones, thus strongly suggesting the master regulatory role of wild-type p53 in the RT4 cell cycle regulation process. The striking similarities between p73 (Fig. 6) and Puma (Fig. 8) expression profiles in both cell types allow us to suggest that the grade-dependent apoptosis observed in Figs. 3 and 4 is tightly regulated, among others, by the ability of p73 to directly trans-activate the pro-apoptotic gene Puma. Interestingly, as it has been previously reported, Puma not only represents a bona fide target gene of $\mathrm{p} 73$, but its expression is critically involved in the Bax-mediated apoptotic process $(53,54)$. In complete accordance with our observations (Fig. 6), $24 \mathrm{~h}$ treatment of MCF7 breast cancer cells with $0.5 \mu \mathrm{M}$ doxorubicin resulted in a notable expression and accumulation of both $p 53$ and $p 73$ gene products (55).

As illustrated in Fig. 6 of the present study, $p 63$ expression was found to retain a grade-dependent character, while in previous reports, its loss has been strongly associated with tumor stage and grade, as well as tumor invasion, lymph node metastasis and deregulation of cell-cell adhesion mechanisms (3), features that clearly reflect the malignancy status of T24 bladder cancer cells. Therefore, since p63 has been shown to essentially contribute to the regulation of apoptosis in human tumors $(54,56)$, the dose-dependent attenuation of its expression in RT4 cells at the mRNA level (Fig. 6) might represent a 'compensatory' mechanism to the $p 53$ - and $p 73$ mediated apoptotic effects of doxorubicin. On the contrary, the complete absence of expression of p63 in T24 cells could likely be due to epigenetic factors, such as methylation, which seems to be detected in more than $60 \%$ of the diagnosed tumors (3), without excluding an alternative scenario of gene impairment or loss.

For a tumor cell to survive in an extremely hostile and stressful microenvironment, it must undergo drastic structural and/or functional alterations. In this process, modified expression and/or mutation of genes essentially involved in the regulation of apoptosis are indispensable, providing cancer cells with both an intrinsic survival advantage and inherent resistance to chemotherapeutic drugs (33). Therefore, while the effectiveness of chemotherapy is also dependent on a number of other factors including systemic drug toxicity due to lack of specificity, rapid drug metabolism, and both intrinsic and acquired drug resistance, there is a wide consensus on the causal relationship between apoptosis and drug-induced cytotoxicity, and the activation of the apoptotic process shown to occur during cancer chemotherapy is thought to be the central point for the successful drug treatment of a tumor (32). In the present study, we have sought to obtain a closer view of the doxorubicin-induced apoptotic program in human urinary bladder cancer cells, as well as the respective expression profile of a number of genes critically involved in the regulation of grade-dependent apoptosis. 
Although Caspases were found to play an important role in the execution of cellular death, mutations in Caspase genes have been detected at low frequency in some tumors, such as colorectal cancer or head and neck carcinoma $(57,58)$. On the contrary, Caspase expression and function were shown to be impaired rather frequently in cancer cells. For example, Caspase- 8 expression was found to be attenuated due to hypermethylation of certain regulatory sequences in both cancer cell lines and tumor samples derived, among others, from neuroblastoma, Ewing's sarcoma, retinoblastoma, rhabdomyosarcoma and SCLC (59-62). In the human bladder cancer cell lines studied here, Caspase-8, -9 and -3 were found to be expressed at both the mRNA and protein levels, while treatment of RT4 and T24 cells with both doxorubicin concentrations ( 1 and $10 \mu \mathrm{g} / \mathrm{ml})$ induced a dose- and grade-dependent activation of Caspase- $8,-9$ and -3 , as well as specific proteolytic cleavage of the characteristic Caspase protein substrates PARP and Lamin A/C, but also of $\mathrm{Bcl}-\mathrm{X}_{\mathrm{L} / \mathrm{S}}$ and $\mathrm{Hsp} 90$ (exclusively in RT4) signaling components, whereas exposure to the drug resulted in a decrease of the cytosolic trimeric form of FasL, as it is clearly demonstrated in Figs. 3 and 4. These observations unambiguously reveal that, upon treatment with either clinically-relevant or clinically-hazardous doses of doxorubicin, both the membrane death receptor (activation of Caspase-8) and the mitochondria (activation of Caspase-9) apoptotic pathways are strongly, albeit differentially, activated for the efficient implementation of the apoptotic death program, which is mainly characterized by subsequent activation of Caspase-3 and specific proteolytic cleavage of Caspase repertoire substrates PARP and Lamin A/C. Interestingly, the drug-induced apoptotic patterns clearly proclaim the gradedependent character of RT4 and T24 cell response to doxorubicin activity, with $\mathrm{T} 24$ being significantly more resistant to apoptosis than RT4.

Moreover, in RT4 cells (grade I), the apoptotic process is accompanied by the cleavage and degradation of the antiapoptotic protein $\mathrm{Bcl}-\mathrm{X}_{\mathrm{L}}$, and its pro-apoptotic isoform $\mathrm{Bcl}-\mathrm{X}_{\mathrm{S}}$, as well as the strong proteolytic cleavage of Hsp90, as evinced through the generation of a $\sim 65 \mathrm{kDa}$ processed fragment (Fig. 3). However, in the more malignant T24 cells (grade III), characterized by the absence of $\mathrm{Bcl}-\mathrm{X}_{\mathrm{S}}$, the short isoform is generated after treatment with the higher dose of doxorubicin only, while, interestingly, no Hsp90 cleavage is detected (Fig. 4). In addition, the drug-induced notable degradation of $\mathrm{Bcl}-\mathrm{X}_{\mathrm{L}}$ and generation of a $21-\mathrm{kDa}$ cleaved form only in the higher doxorubicin dose clearly dictate its critical role in the regulation of human bladder cancer cell apoptosis. In the case of apoptotic ligand FasL (Figs. 3 and 4), a notable decrease $(1 \mu \mathrm{g} / \mathrm{ml})$ or obliteration $(10 \mu \mathrm{g} / \mathrm{ml})$ of its cytosolic trimeric form (120 kDa) occurs in both cell lines in a dose- and gradedependent fashion. The observed induction of $\mathrm{Bcl}-\mathrm{X}_{L}$ at the mRNA level (Fig. 10) after treatment of RT4 cells with the lower dose of doxorubicin was possibly due to a "compensatory' response to the cleavage of the $\mathrm{Bcl}-\mathrm{X}_{\mathrm{L}}$ protein, whereas in T24 cells, characterized by an absence of such cleavage in the same drug dose conditions $(1 \mu \mathrm{g} / \mathrm{ml})$, there has been a clear down-regulation of the $B c l-X_{L}$ mRNA. On the other hand, induction of FasL at the mRNA level (Fig. 7) could be also attributed to a similar 'compensatory' effect to the diminishing cytosolic pool of trimeric FasL protein migrating to the cell membrane as a response to the apoptotic insult of doxorubicin $(23,25)$, as well as to the putative shedding of FasL by MMP-7 or other proteases specifically activated during the apoptotic process $(63,64)$.

Regarding Hsp90, due to its chaperoning role in the maturation and stability of a variety of client proteins that play important roles in cell proliferation, apoptosis, and other cellular processes, inhibition of the functional chaperone has been shown to induce degradation of these clients. Therefore, much attention was recently drawn on Hsp90 targeting in cancer therapy due to its assumed ability to disrupt multiple signal transduction pathways $(26,28)$. One of the novel findings of the present study is that Hsp90 was shown, for the first time, to be specifically cleaved in response to doxorubicin treatment in RT4 cells, whereas no such proteolytic cleavage was observed in T24 cells (Figs. 3B and 4B). Using the GrabCas software (65), we have identified a high probability Granzyme B recognition and cleavage site (VGSDEE) in the amino acid sequence of both Hsp90 $\alpha$ (aa 261-266) and Hsp90ß (aa 253-258) proteins. However, using the same software program, no high probability cleavage site for any Caspase family member fitting to the molecular weight of the Hsp90 cleavage product $(65 \mathrm{kDa})$, exclusively observed in RT4 cells (Fig. 3B), could be identified. Since the monoclonal antibody used in the present study can specifically bind to the carboxylterminal region of Hsp90, we suggest that the $65 \mathrm{kDa}$ cleaved form represents an amino-terminally truncated fragment of the protein, which is likely generated through a Granzyme Bmediated proteolytic processing of Hsp90. The RT4-specific production of the $65 \mathrm{kDa}$ proteolytic fragment could likely result in a severe perturbation of Hsp90 chaperone activity, eventually causing inhibition of multiple signaling pathways also involved in the regulation of cell cycle progression and apoptosis. Interestingly, to strengthen the validity of our observations, there have been some recent reports on Caspaseor Granzyme B-dependent cleavage of the Hsp90 and Hsp70 co-chaperones p23, Hop and Hip during drug-induced cell death (66-68). The fact that no cleavage of Hsp90 was detected in T24 cells, in response to any dose of doxorubicin used, could possibly be due to either a grade-dependent expression of Granzyme B (i.e. suppressed in T24, but not in RT4) or a grade-specific phosphorylation of the serine residue located in the putative Granzyme B cleavage site, likely regulating the cleavability and further processing of Hsp90 (69). A more complex alternative would be the escape of Hsp90 from the cleavage machinery (i.e. Granzyme B) due to potential formation of tumor-specific (i.e. T24) Hsp90 protein complexes, with eventual selective masking of certain chaperone's epitopes $(26,70)$.

In an attempt to characterize the different subgroups of human urinary bladder tumors in a more efficient and reliable way, gene expression profiles are expected to have an important contribution to the prediction of patient prognosis, along with the current major determinants of clinical outcome, such as histological classifications and other clinicopathological characteristics $(71,72)$. On the other hand, trying to reduce mortality rates for some cancer types, a considerable effort has been devoted to the identification of biomarkers that could predict a patient's response to specific chemotherapy drugs more effectively (73). These biomarkers of response 
mainly include groups of genes differentially expressed before, during and after therapy. Since cancer cell lines have been shown to maintain the in vivo patterns of gene expression, which represent the stage of progression of their tumors of origin, this renders in vitro experiments using cell lines valuable tools in the identification and characterization of response biomarkers. On the other hand, the expression patterns of individual genes are frequently shown to be insufficient enough to serve as reliable biomarkers of response for most chemotherapeutic drugs in the clinical practice (73). Therefore, in the present study, together with the genes involved in cell cycle progression (Figs. 5 and 6), which have been discussed earlier, we have analyzed the expression of 29 genes implicated in the regulation of apoptosis (Figs. 7-10), in order to possibly identify a subset of genes that might be of use in the prognosis and/or response to doxorubicin activity in human bladder cancer cells.

In general, the lower doxorubicin concentration used in this study was shown to induce differential response in the expression of most genes, in both cell lines (Figs. 5-10). On the contrary, the changes in gene expression were a lot more uniform in the case of the higher concentration of doxorubicin, where there was a clear down-regulation at the mRNA level in almost all (with the exception of Cyclin-D, GAPDH, FasL, Tweak and Noxa) (RT4) or at least in 2/3 (T24) of the genes examined. This could be because topoisomerase II inhibition by doxorubicin has been shown to cause dramatic changes in the function of transcription complexes at or near promoters. These changes were found to be mainly due to high levels of torsional stress created by hypernegatively supercoiled DNA that finally prevented transcription $(29,30)$. Therefore, besides the disturbance provoked by the dissipation of torsional strain and/or the hindering of the movement of transcription elongation machinery by the immobilized topoisomerasedoxorubicin-DNA ternary complexes, the overall effect of topoisomerase II inhibition, differentially affecting the expression of diverse genes, may be also attributed to: a) the inhibition of the transcription apparatus by deregulating direct protein-protein interactions of topoisomerase II with certain transcription factors, the basal transcription apparatus or chromatin modifying/remodeling machinery and/or b) the activation of the signal transduction pathways regulating DNA repair (29).

Activation of Caspases can be initiated with the activation of membrane death receptor and/or the mitochondrial pathways. During drug treatment, ligation of FasL and/or TRAIL to the appropriate death receptors can result in the activation of initiator Caspase-8. Both FasL and its cognate receptor Fas were found to be expressed at high levels in most samples of, among others, breast tumor $(74,75)$, hepatoblastoma (76), leukemia $(77,78)$, and myeloma (79), while FasL expression was demonstrated to be positively correlated with histological grading in breast cancer (80). In urothelial cancers, FasL expression exhibited an inverse correlation with tumor grade and stage, while decreased Fas expression was significantly associated with more advanced stage, higher pathological grade and poorer prognosis of the disease (81). In a syngeneic tumor model of Lewis lung carcinoma cells (3LL) in mice, doxorubicin was found to inhibit growth of the 3LL-induced solid tumors, both in wild-type and Fas-deficient mice, whereas it failed to do so in mice lacking a functional FasL, strongly suggesting that the interaction between host FasL and tumor Fas is critically involved in the antitumor effect of doxorubicin (82). Moreover, while an altered pattern of Fas/FasL expression in breast cancer patients receiving adjuvant anthracycline-based chemotherapy was demonstrated to configure an aggressive tumor phenotype, linked to disease progression (83), topoisomerase II inhibitors that cause DNA damage were shown to strongly induce FasL expression, contrary to non-DNA damaging catalytic topoisomerase II inhibitors, whose biological activities did not seem to affect FasL expression (84).

In one study, poorly-differentiated T24 cells were shown to be relatively insensitive towards an agonistic apoptosisinducing monoclonal antibody against Fas. In the same report, in co-culture experiments, T24 cells were able to induce apoptosis in Jurkat cells (85), which would imply that, while FasL is functionally active, the Fas pathway is, at least partly, inhibited in T24 cells, or differently the membrane Fas complexes have acquired altered conformations, rendering them relatively insensitive to the cytotoxic activity of Fas monoclonal antibody, but still partly responsive to FasL. Taken together, all the above data suggest that bladder cancer cells are possibly able to evolve a mechanism of immune evasion during transformation to higher-grade malignant state and that a functional FasL/Fas pathway is essential for the control of disease progression and a strong response to doxorubicin treatment. In the present study, FasL and Fas were both found to be expressed in the bladder cancer cell lines used (Figs. 7 and 8), with RT4 cells expressing less FasL than T24, while in both cell lines FasL was strongly induced in response to either dose of doxorubicin. On the other hand, Fas was shown to be notably induced in RT4 cells in response to the lower dose of doxorubicin, whereas its expression was severely attenuated in T24 drug-treated cells. These results on FasL and Fas expression profiles correlate well with the gradedependent apoptotic death observed in response to doxorubicin treatment in RT4 and T24 cells (Figs. 3 and 4). And although the functional integrity of the Fas pathway was not directly assayed here, its signaling potency does not seem to be inhibited, as evinced by the drug-induced Caspase- 8 activation in a TRAIL minus background, but rather to be playing a significant role in the apoptotic process initiated by doxorubicin in both human bladder cancer cell lines.

Apoptotic ligand TRAIL has been found to be expressed at different levels in a variety of tissues. For example, in one study, it was detected in only half of the breast cancer tissues, but not in the normal breast samples examined (75). Moreover, four out of ten human HCC bioptic tissue specimens demonstrated positive staining for TRAIL, whereas non-tumor tissues showed little detectable staining (86). On the other hand, TRAIL death receptors DR4 and DR5 were found to be expressed in normal tissues and in many types of tumor cells as well, whereas its decoy receptors DcR1 and DcR2 were frequently detected in normal tissues but rarely in tumor cells (87). DR4 and DR5, together with their ligand TRAIL, were all shown to be expressed in four human colonic adenocarcinoma cell lines, while after doxorubicin treatment a TRAIL upregulation was observed (88). Furthermore, in three hepatocellular carcinoma cell lines TRAIL was found to be 
constitutively expressed and its expression was dramatically induced after the addition of doxorubicin (86).

In the present study, TRAIL was expressed at low levels in RT4 cells, but almost not at all in T24, while it was found to be drug-induced in both cell lines. However, even though RT4 cells are characterized by a strong TRAIL upregulation under the lower dose of doxorubicin, T24 are weakly responsive to the same drug conditions. All TRAIL receptor genes were expressed in both bladder cancer cell lines and their activities were induced by the lower dose of doxorubicin (except DR4 in T24 cells). The drug-dependent upregulation of TRAIL and its cognate receptors DR4 and DR5 strongly suggest an important role in the apoptotic process that follows treatment of RT4 cells with $1 \mu \mathrm{g} / \mathrm{ml}$ of doxorubicin, while the weak expression of TRAIL, together with the moderate down-regulation of $D R 4$ expression, in T24 drug-treated cells correlate well with the poorer differentiation grade of the latter cell line, as well as with its relatively mild apoptotic response to doxorubicin activity.

Expression analysis of OPG, a soluble molecule thought to be the third decoy receptor of TRAIL, demonstrated that OPG was expressed in $19 \%$ of surgical biopsy specimens from primary carcinomas, whereas in metastatic prostate cancer it was found in $73 \%$ of the examined samples (89). Furthermore, OPG production was more commonly recognized in skeletal $(83 \%)$ as compared with lymph node $(46 \%)$ metastases, while increased expression of OPG correlated with stage, grade, androgen status and serum PSA levels, suggesting a role as diagnostic, prognostic and therapeutic target for prostate cancer (89). In addition, the mean serum OPG concentration in patients with bladder carcinoma has been measured to be approximately three times higher than the one corresponding to healthy individuals (90). Among patients with bladder carcinoma, higher tumor stage and grade were found to be associated with increased serum OPG levels. Therefore, elevated serum OPG concentrations are suggested to be predictive of early recurrence in patients with bladder carcinoma (90). Moreover, expression of OPG was low in normal but markedly higher in prostate cancer cell lines (89). In the bladder cancer cell lines used here, $O P G$ could not be detected in the low grade RT4 cell line, whereas it was shown to be notably expressed in the high grade T24 cells, though its expression was completely obliterated after doxorubicin treatment. A clearly different pattern of $O P G$ transcriptional activity profile was observed in T24 cells after they have been treated with the chemotherapeutic drug taxol, a microtubule depolymerization blocking agent. Contrary to doxorubicin, the lower concentration of taxol did not affect $O P G$ expression, whereas the higher concentration of the drug induced a marked gene upregulation (Fig. 9). Taken together, all these data: a) are in absolute agreement with the observed grade-dependent increase in $O P G$ expression reported in previous studies, b) reinforce the arguments for the involvement of doxorubicin activity in the inhibition of gene transcription (however, in a gene-specific manner) and c) strongly suggest $O P G$ as a sensitive biomarker for prognosis and response to doxorubicin treatment in human bladder cancer.

The mitochondrial pathway of apoptosis is initiated by the release of apoptogenic factors, such as Cytochrome c, apoptosis-inducing factor (AIF), Smac/DIABLO, Omi/HtrA2, Endonuclease G, Caspase-2 and/or Caspase-9, from the mitochondrial inter-membrane space. The shuffling of Cytochrome $\mathrm{c}$ into the cytosol triggers Caspase- 3 activation through formation of the Cytochrome c/Apaf-1/Caspase-9-containing apoptosome complex, while Smac/DIABLO and Omi/HtrA2 promote Caspase activation through functional neutralization of the inhibitory effects of IAPs. Important players in this pathway are all the Bcl-2 family members, which are divided into two major groups: a pro-apoptotic and an anti-apoptotic group. The pro-apoptotic Bcl-2 family group consists of the multi-domain pro-apoptotic subgroup, comprising Bax, Bak, Bok and Bcl-rambo, and the BH3-only protein subgroup, containing Bik, Bim, Noxa, Puma, Bad, Bid, Hrk, Blk, Bmf, Bnip3, Bnip3L, p193 and Bcl-G family members (33). The indirect initiator of apoptosis Bik was found to be overexpressed in breast cancer (91), in high-risk stage I NSCLC patients (92), as well as in gastric cancer patients with lymph node metastases (93), while it showed a consistent loss of expression in primary RCC tissues and cell lines (94), also having been identified as a critical target of deletion or epigenetic silencing in glioma cell lines and primary tumors $(95,96)$. Furthermore, Bik was demonstrated to be induced by doxorubicin in lymphoma and myeloma cell lines (97), as well as in MCF-7, but not in T47D or SKBr3 cells, whereas it was constitutively expressed in ZR75-I cells (98). In the present study, Bik transcriptional activity was found to be significantly induced by the lower concentration of doxorubicin both in RT4 and T24 cells (Fig. 7), thus indicating an important role played by the gene in doxorubicin-induced apoptosis in bladder cancer cells. Although Bik gene has been previously suggested to be directly controlled by the p53 transcription factor, through an incomplete (and likely weak) p53-binding element contained in the Bik promoter, the observed upregulation of its transcriptional activity in both wild-typep53 RT4 and mutant-p53 T24 cells argues in favor of a p53independent doxorubicin-induced expression of Bik, thus requiring the involvement of other transcription factors, possibly the E2F family members (98-100).

Unlike Bik, which possesses a $\mathrm{BH} 3$ domain only and is able to serve as ligand or facilitator of the pore-forming $\mathrm{Bcl}-2$ proteins, Bax, Bak and Bok bear conserved BH1, BH2, BH3 and TM domains and can efficiently induce apoptosis through channel formation, in addition to their role as ligands for the anti-apoptotic Bcl-2 proteins (101). Bax and Bak were found to be expressed at different levels in various human cancers. For example, they were both detected in cervical cancer, with the percentage of cases expressing Bax being correlated well to a longer disease-free survival time, while Bax expression in patients with no evidence of disease after treatment was significantly higher compared with patients currently suffering or having been deceased by the disease (102). In another study, Bak expression in keratoacanthomas was shown to be notably upregulated in comparison with normal skin tissues, whereas a significant reduction of Bak expression in poorlydifferentiated squamous cell carcinoma of the skin was observed (103). Furthermore, many synovial sarcomas were found to be diffusely positive for Bax and Bak, but for Bcl-2 and $\mathrm{Bcl}-\mathrm{X}_{\mathrm{L}}$ as well, thus suggesting that the increased rate of apoptosis should be considered as an indicator of poor 
prognosis in primary synovial sarcoma (104). Conversely, a loss of expression for Bax and Bak was recorded in mesothelioma (105), gastric cancer (106), NSCLC (107), SCLC, where expression of both Bcl-2 and Bax was shown to be reduced and development of metastatic clones resistant to apoptosis was observed (108), and in superficial-spreading melanoma, where the reduction in Bax and Bak expression was significantly correlated with poor prognosis (109). Moreover, reduced Bax levels were associated with the ex vivo resistance to B-CLL therapy using doxorubicin (110). Bax- as well as Bak-deficient MEFs were found to be unresponsive to doxorubicin, compared to the wild-type cells, suggesting a role for these proteins as critical apoptotic regulators of doxorubicin cytotoxic activity. Additionally, doxorubicin induced apoptosis was completely blocked in $\mathrm{Bcl}$-2-overexpressing myeloma cells, whereas in $\mathrm{Bcl}$-2-transfected cells Bak activation was hampered, while Bax was able to partially retain its functional activity, in agreement with the differential regulation of these two pro-apoptotic proteins (97). In A2780 ovarian cancer cells, exposure to doxorubicin induced Bax upregulation (111), whereas the intracellular concentration of Bcl-2 and Bax did not change significantly in HL-60 cells after treatment with doxorubicin (112).

In the present study, Bax was shown to be moderately induced in response to low dose of doxorubicin treatment in RT4 cells, whereas it was notably down-regulated in T24 cells under the same drug conditions, observations tightly associated with the grade-dependent character of RT4 and T24 apoptotic response to doxorubicin activity. On the other hand, Bak expression was found to be attenuated in a drug dose-dependent and grade-specific manner, with T24 exhibiting a more severe reduction, thus partly vindicating the gradedependent character of doxorubicin-induced apoptosis in RT4 and T24 cells. Intriguingly, Bik gene, whose product represents the apical regulator of Bak-dependent apoptotic pathway, was significantly upregulated by the lower dose of doxorubicin (Fig. 7) in a presumable cellular effort to functionally 'compensate' the drug-induced reduction of Bak expression at the mRNA level in both cell lines. Interestingly, Bax expression levels, after being initially reduced in response to the lower dose of doxorubicin in T24 cells, they were upregulated again after treatment with the higher drug concentration. Similar expression profiles with Bax in T24 cells, mainly characterized by down-regulation in the lower and comparative upregulation in the higher drug dose (albeit, still suppressed in comparison to the control samples), are demonstrated for other genes examined (i.e. Cyclin-B2 and $X A F-1)$, likely representing part of an integrated cellular response exclusively activated and solely developed under higher drug dose conditions.

Regarding the expression of the multi-domain pro-apoptotic protein Bok in human cancers, little epidemiological data exist in the literature. Bok was found to be upregulated in estrogen-dependent breast cancer, while it was down-regulated in hyperplasia but not in adenoma of the parathyroid gland $(113,114)$. Nevertheless, Bok, which does not seem to interact with Bcl-2 or Bcl- $\mathrm{X}_{\mathrm{L}}$, and was shown to be a critical target of antagonism for binding between the anti-apoptotic proteins Mcl-1, Bfl-1 and EBV-derived protein BHRF1, and the BH3only pro-apoptotic Bcl-2 family members, constitutes (together with Noxa) an essential mediator of p53-dependent apoptosis in neuroblastoma and breast cancer cells (115). Interestingly, contrary to the 'expected' gene activity profile, as evinced in this study, Bok was hardly expressed in RT4 cells, whereas its expression levels in T24 cells demonstrated a dose-dependent reduction in response to doxorubicin activity. The biological significance of grade-specific and/or severely attenuated drug dose-dependent transcriptional expression of a number of genes examined in the present study is currently under extensive investigation in our laboratories.

The anti-apoptotic members of the Bcl-2 family, namely Bcl-2, Bcl-X $\mathrm{L}$, Bcl-w, Mcl-1, Bfl-1 and Boo, possess sequence homology within three or four $\mathrm{BH}$ domains, and they are mainly localized to the outer membrane of mitochondria, whereat they prevent the release of Cytochrome $\mathrm{c}$ and other pro-apoptotic proteins from mitochondrial inter-membrane space into the cytosol. $\mathrm{Bcl}-2$ or $\mathrm{Bcl}-\mathrm{X}_{\mathrm{L}}$ have been found to be overexpressed in follicular lymphomas (116), as well as in several other cancers, such as SCLC (117), chronic lymphocytic leukemia (118), multiple myeloma (119), melanoma (120), bladder (121), prostate (122), ovarian (123), cervical (124), gastric (125), breast (126) and colorectal (127) cancers. In most of these cancers, overexpression of Bcl-2 or Bcl- $\mathrm{X}_{\mathrm{L}}$ correlated well with poor prognosis, whereas, on the contrary, in breast and colorectal cancer, upregulation of Bcl-2 was linked to a favorable outcome and improved survival. In superficial bladder cancer, an increased $\mathrm{Bcl}-2 / \mathrm{Bax}$ ratio was suggested to predict relapses (128), whereas $\mathrm{Bcl}-\mathrm{X}_{\mathrm{L}}$ overexpression was found to be frequently observed, however likely reflecting its expression pattern in normal urothelium (129). In another study, in patients with bladder cancer expressing both Bcl-2 and p53, there was evidence for a poor outcome after radiotherapy (130). Upregulation of $B c l-2$ or $B c l-X_{L}$ was shown to occur in various cancer cell lines as well, usually resulting to resistance against a variety of chemotherapeutic agents. $B c l-X_{L}$ overexpression in different hepatoma cell lines effectively blocked apoptosis that was induced by high dose of doxorubicin, through inhibition of the loss of mitochondrial membrane potential, release of mitochondrial Cytochrome c and activation of Caspase repertoire (131). Likewise, $B c l-2$ overexpression was revealed to potentiate the malignant phenotype of anaplastic thyroid cancer cells by limiting the response to apoptosis-inducing chemotherapeutic drugs and enhancing proliferation and tumor aggressiveness (132). Interestingly, the same cells overexpressing an exogenous $\mathrm{Bcl}-2$ gene exhibited an enhanced resistance to doxorubicin activity than control cells, although they were 'unexpectedly' characterized by increased transcript levels of Caspase-9, Caspase-8, Bik, Bok and Bmf. In this case, an oncogenic 'addiction' of cells to Bcl-2 was hypothesized to explain the 'discrepancy' (133).

According to our studies, $B c l-2$ and $B c l-X_{L}$ genes were found to be expressed in both cell lines, although the transcript levels of $B c l-2$ were significantly lower compared to the $B c l-X_{L}$ ones. In other reports, Bcl-2 overexpression in bladder cancer cell lines was shown to be associated with resistance to doxorubicin-triggered apoptosis (134), while Bcl-2 antisense oligonucleotides combined with doxorubicin were able to overcome resistance to drug-induced apoptosis in highly 
malignant bladder cancer cells (135). In the present study, we have observed a notable upregulation of $B c l-X_{L}$ expression in the presence of lower doxorubicin dose in RT4 cells, which was reversed to a severe down-regulation after treatment with the higher dose of the drug. On the contrary, in T24 cells there was a clear drug-dependent down-regulation of $\mathrm{Bcl}-\mathrm{X}_{L}$ expression, which remained constant in both the lower and higher doxorubicin concentrations. The observed $\mathrm{Bcl}-\mathrm{X}_{L}$ transcriptional induction, which is accompanied by a similar upregulation of $\mathrm{Mcl}-1$ in lower drug dose-treated RT4 cells, could be ascribed to a 'compensatory' response to p53dependent upregulation of Puma (Fig. 8), since it is known that a number of anti-apoptotic proteins, including $\mathrm{Bcl}-\mathrm{X}_{\mathrm{L}}$ and Mcl-1, are able to bind and sequester Puma (136). Another alternative would be the upregulation of $B c l-X_{L}$ expression in order to favor the formation of the tripartite $\mathrm{Bcl}-\mathrm{X}_{\mathrm{L}}$, Puma and p53 complex (all three genes notably induced by the lower dose of doxorubicin in RT4), which has been shown to coordinate the distinct pro-apoptotic functions of p53 (137). In the latter case, down-regulation of $B c l-X_{L}$ in response to the lower dose of doxorubicin in T24 cells could be justified by the existence of mutant $p 53$ in these cells, while a 'compensatory' slight upregulation of $p 53$ gene expression observed in the same cells would prove non-prosperous, due to presumable inability of forming a Bcl- $\mathrm{X}_{\mathrm{L}}$, Puma and mutant p53 functional complex. In support to this latter scenario, 553 knockdown in keratinocytes was shown to be accompanied by accelerated elimination of $\mathrm{Mcl}-1$ and $\mathrm{Bcl}-\mathrm{X}_{\mathrm{L}}$ anti-apoptotic proteins, although this mechanism was not analyzed at the mRNA level (138). Interestingly, possibly owing to the mutant p53 genetic locus, the transcriptional expression profiles of a number of p53 target genes, such as $p 21^{\text {Cipl }}$, GADD45A, Fas, DR4, Bax and Puma, seem to be significantly suppressed in a rather dose-dependent manner. On the other hand, the observed upregulation of FasL, DR5 and DcR2 genes or stable expression of Noxa gene at the mRNA level after drug administration in T24 cells is obviously p53-independent. Nevertheless, the basal levels of mRNA expression of all the above p53 target genes (namely, p21 Cipl GADD45A, Fas, DR4, Bax, Puma, FasL, DR5, DcR2 and Noxa) in the untreated cells do not seem to be severely affected by the mutational status of $p 53$ gene in T24 compared to RT4. This argues in favor of a p53independent additional level of regulation of these genes.

Bcl-2 transcript expression levels were readily detectable but relatively low in both bladder cancer cell lines examined in the present study. In RT4 cells, $B c l-2$ gene activity was severely suppressed by both concentrations of doxorubicin, whereas a partial down-regulation was observed in T24 cells under similar treatment conditions. The differences in $\mathrm{Bcl}-2$ expression patterns in response to doxorubicin, revealed here, likely reflect the different grade of malignancy in the two cell lines. Dissimilarly to doxorubicin, a clearly different expression profile of $\mathrm{Bcl}-2$ was observed after treatment of RT4 and T24 cells with taxol chemotherapeutic drug (Fig. 9). As in the case of $O P G$ in the lower taxol dose-treated T24 cells, $B c l-2$ transcriptional activity remained rather unaffected in both cell lines and in both concentrations of the drug tested (taxol), thus demonstrating the specificity of the cellular responses to distinct apoptotic stimuli (i.e. drugs), and the drug-specific ability of the lower doxorubicin concentration to inhibit transcription of individual genes.

The IAPs constitute fundamental negative regulators of apoptosis either by direct binding to Caspases or by other indirect modes of action (139). They are characterized by one or more protein modules of 70 amino acids called baculovirus IAP repeat (BIR) domains (140). Survivin, a representative member of this anti-apoptotic group of proteins, which forms stable homodimers in solution, has been strongly implicated in multiple essential cellular functions, including cell division, apoptosis, stress response and checkpoint mechanisms of genomic integrity (141). Thus, its expression was able to protect normal or transformed cells from apoptosis and was clearly detected, although at different levels, in all 60 cancer cell lines of the NCI panel (142). Moreover, Survivin gene was found to be transcriptionally active during development and in proliferating cells as well, whereas it was largely suppressed in most differentiated tissues in the absence of stress conditions. On the contrary, high expression levels of Survivin could be observed in solid tumors and hemopoietic cancers, which correlated well to resistance against chemotherapy-induced apoptosis and poor prognosis (143-146). In addition, Survivin was identified as a diagnostic biomarker in urine for bladder cancer onset and recurrence (147). Furthermore, transcriptional silencing of Survivin in SKBr-3 and HeLa cells, expressing high levels of the relative protein, by siRNA was able to restore sensitivity to doxorubicin (143).

In our cellular system, Survivin was found to be rather equally expressed in both RT4 and T24 cells. However, even though both concentrations of doxorubicin were able to annihilate its expression in RT4 cells, Survivin expression levels not only remained unaffected in the lower drug dosetreated T24 cells, but interestingly they were shown to be notably induced in the higher concentration of doxorubicin. On the contrary, the lower dose of taxol was able to slightly induce Survivin gene activity in both cell types, probably as a 'compensatory' reaction to the effects of taxol on microtubule depolymerization, since Survivin overexpression is known to suppress microtubule growth, thus critically regulating microtubule nucleation and dynamics (148). The grade-dependent response to doxorubicin observed in $O P G, B c l-2$ and Survivin gene expression (as also compared to taxol) (Fig. 9) may lay extra emphasis on the powerful properties of doxorubicin to regulate transcription in a gene-specific fashion, as we had the opportunity to repeatedly encounter during the course of the present study. Based on the data presented here on $\mathrm{Bcl}-2$, $O P G$ and Survivin expression, it would be reasonable to recommend these genes as potent biomarkers of response to doxorubicin activity during chemotherapy of human bladder cancer [i.e. one could interestingly observe the drug-dependent expression profiles of Bcl-2 and Survivin in RT4 cells and $O P G$ in $\mathrm{T} 24$ cells, in response to either doxorubicin or taxol cytotoxic activities (Fig. 9)].

In summary, here, we have examined the cytotoxic effects of different concentrations of doxorubicin in the regulation of cell cycle progression and apoptosis in two human urinary bladder cancer cell lines of different malignancy grade (I and III), while we have also explored the possibility of using a group of genes as biomarkers of response to doxorubicin treatment in the same cancer cells. The presented data demon- 
strate that, depending on the dose administered, doxorubicin induces a $\mathrm{G} 2 / \mathrm{M}$ and/or a $\mathrm{G} 1 / \mathrm{S}$ cell cycle block in bladder cancer cell lines, followed by cell death through activation of both the membrane death receptor and the mitochondrial pathways of apoptosis. Grade-dependent activation of Caspase-8, Caspase-9, and finally Caspase-3, resulted in the cleavage of PARP, Lamin A/C, and $\mathrm{Bcl}-\mathrm{X}_{\mathrm{L} / \mathrm{S}}$ cognate protein substrates, whereas the observed drug-induced cleavage of Hsp90 ( $65 \mathrm{kDa}$ ), exclusively detected in RT4 cells, could be likely ascribed to the action of Granzyme B. Furthermore, a drug-dependent reduction in the amount of the cytosolic trimeric form of FasL was observed.

Moreover, a group of 15 genes have been unveiled to exhibit a potent grade-dependent expression pattern, with their respective transcript levels demonstrating great differences in the two bladder cancer cell lines. This group includes Cyclin-E2, Cyclin-B2, Cyclin-F, p53, p63, p73, FasL, TRAIL, Tweak, Tweak-R, Caspase-8, XAF-1, OPG, Bok and Bid genes. Among these, the transcript expression patterns of Cyclin-E2, Cyclin-F, p63, p73, FasL, TRAIL, Tweak, Tweak-R, $X A F-1, O P G$ and $B o k$ (11 in number) genes are being further examined for possible use in the identification of differentiation/malignancy grade in human urothelial carcinomas.

Based on their response to the clinically-relevant $(1 \mu \mathrm{g} / \mathrm{ml})$ concentration of doxorubicin treatment, the apoptotic genes studied here could be classified into three distinct categories: one, exhibiting a grade-independent pro-apoptotic response, including FasL, Bik, Bim and Caspase-3 (4 genes); a second, demonstrating a grade-dependent pro-apoptotic response, harboring TRAIL, Fas, DR4, DR5, Tweak-R, Caspase-8, Caspase-10, Bak-1, Bax, XAF-1, Puma, Bcl-2, Survivin and $O P G$, while also embracing $p 53$ and $p 73$ (16 genes); and a third, displaying a grade-dependent (in most cases) 'compensatory' reaction to the drug, containing $D c R 2, B o k$, Bcl-X $X_{L}, M c l-1, F L I P$, Smac/DIABLO, cIAP-1 and Caspase-9, also embracing $p 63$ (9 genes). From all the genes studied here, certain subgroups could be selected for use in the evaluation of response of bladder cancer cells to clinically-relevant doses of doxorubicin, regardless of the tumor differentiation grade. Thereby, the most promising candidates, among others, seem to be Cyclin-B2, GADD45A, p73, FasL, Bik, Bim, TRAIL, Fas, Tweak-R, XAF-1, Bcl-2, Survivin, OPG, DcR2 and Bcl- $X_{L}$ (15 genes). Therefore, we believe that the development of such a small-scale gene profiling 'mini-microarray' tool (Fig. 11) could undoubtedly detect responses to doxorubicin in human bladder cancer cells irrespective of malignancy grade, thus significantly contributing to the clinical management of the disease.

\section{Acknowledgements}

We are deeply grateful to Dr Harris Pratsinis (Laboratory of Cell Proliferation and Ageing, Institute of Biology, NCSR 'Demokritos', Athens, Greece) for his scientific advice and support in cell cycle analysis and to Dr Dimitris Kletsas (Laboratory of Cell Proliferation and Ageing, Institute of Biology, NCSR 'Demokritos', Athens, Greece) for his valuable suggestions and productive criticism during the implementation of the present study. Panagiotis K. Karkoulis is financially supported by a fellowship awarded from the Institute of
Biology, NCSR 'Demokritos', Athens, Greece (Ph.D. fellowship) (Ministry of Development), while Eumorphia G. Konstantakou is a scholarship recipient of the Hellenic State Scholarships Foundation ('IKY') (Ph.D. fellowship). Financial support was from the Greek Ministry of Health and Social Solidarity ( $\Delta$ Y 2ß/OIK.128320/30-11-2005) and the Hellenic Society of Medical Oncology (HESMO) (1176/18-09-2007). Finally, Dr Dimitrios J. Stravopodis would like to devote the present article to the memory of his lovely cousins Dena and Leo Lauren, who so unfairly passed away three and a half years ago in the city of St. George, Utah (UT), USA, in a fatal car accident, while Dr Gerassimos E. Voutsinas would like to dedicate this article to the memory of his father.

\section{References}

1. Clark PE: Bladder cancer. Curr Opin Oncol 19: 241-247, 2007

2. Wu XR: Urothelial tumorigenesis: a tale of divergent pathways. Nat Rev Cancer 5: 713-725, 2005.

3. Mhawech-Fauceglia P, Cheney RT and Schwaller J: Genetic alterations in urothelial bladder carcinoma: an updated review. Cancer 106: 1205-1216, 2006.

4. Mitra AP, Datar RH and Cote RJ: Molecular staging of bladder cancer. BJU Int 96: 7-12, 2005.

5. Williams SG and Stein JP: Molecular pathways in bladder cancer. Urol Res 32: 373-385, 2004.

6. Minotti G, Menna P, Salvatorelli E, Cairo G and Gianni L: Anthracyclines: molecular advances and pharmacologic developments in antitumor activity and cardiotoxicity. Pharmacol Rev 56: 185-229, 2004.

7. Rabbani A, Finn RM and Ausio J: The anthracycline antibiotics: antitumor drugs that alter chromatin structure. Bioessays 27 : 50-56, 2005.

8. Kellner U, Sehested M, Jensen PB, Gieseler F and Rudolph P: Culprit and victim - DNA topoisomerase II. Lancet Oncol 3: 235-243, 2002

9. Dinney CP, McConkey DJ, Millikan RE, Wu X, Bar-Eli M, Adam L, Kamat AM, Siefker-Radtke AO, Tuziak T, Sabichi AL, Grossman HB, Benedict WF and Czerniak B: Focus on bladder cancer. Cancer Cell 6: 111-116, 2004.

10. Raghavan D: Molecular targeting and pharmacogenomics in the management of advanced bladder cancer. Cancer 97: 2083-2089, 2003.

11. Fornari FA Jr, Jarvis DW, Grant S, Orr MS, Randolph JK, White FK and Gewirtz DA: Growth arrest and non-apoptotic cell death associated with the suppression of c-myc expression in $\mathrm{MCF}-7$ breast tumor cells following acute exposure to doxorubicin. Biochem Pharmacol 51: 931-940, 1996.

12. Benchekroun MN, Sinha BK and Robert J: Doxorubicin-induced oxygen free radical formation in sensitive and doxorubicinresistant variants of rat glioblastoma cell lines. FEBS Lett 326: 302-305, 1993. [Erratum published FEBS Lett 322: 295-298, 1993].

13. Feinstein E, Canaani E and Weiner LM: Dependence of nucleic acid degradation on in situ free-radical production by adriamycin. Biochemistry 32: 13156-13161, 1993.

14. Swift LP, Rephaeli A, Nudelman A, Phillips DR and Cutts SM: Doxorubicin-DNA adducts induce a non-topoisomerase IImediated form of cell death. Cancer Res 66: 4863-4871, 2006.

15. Skladanowski A and Konopa J: Interstrand DNA crosslinking induced by anthracyclines in tumour cells. Biochem Pharmacol 47: 2269-2278, 1994

16. Tuteja N, Phan TN, Tuteja R, Ochem A and Falaschi A: Inhibition of DNA unwinding and ATPase activities of human DNA helicase II by chemotherapeutic agents. Biochem Biophys Res Commun 236: 636-640, 1997.

17. Vichi $\mathrm{P}$ and Tritton TR: Adriamycin: protection from cell death by removal of extracellular drug. Cancer Res 52: 4135-4138, 1992.

18. Gewirtz DA: A critical evaluation of the mechanisms of action proposed for the antitumor effects of the anthracycline antibiotics adriamycin and daunorubicin. Biochem Pharmacol 57: 727-741, 1999.

19. Kaufmann SH: Cell death induced by topoisomerase-targeted drugs: more questions than answers. Biochim Biophys Acta 1400: 195-211, 1998. 
20. Siu WY, Lau A, Arooz T, Chow JP, Ho HT and Poon RY: Topoisomerase poisons differentially activate DNA damage checkpoints through ataxia-telangiectasia mutated-dependent and -independent mechanisms. Mol Cancer Ther 3: 621-632, 2004.

21. Roos WP and Kaina B: DNA damage-induced cell death by apoptosis. Trends Mol Med 12: 440-450, 2006.

22. Reeve JL, Szegezdi E, Logue SE, Chonghaile TN, O'Brien T, Ritter T and Samali A: Distinct mechanisms of cardiomyocyte apoptosis induced by doxorubicin and hypoxia converge on mitochondria and are inhibited by Bcl-xL. J Cell Mol Med 11: 509-520, 2007.

23. Schneider P, Holler N, Bodmer JL, Hahne M, Frei K, Fontana A and Tschopp J: Conversion of membrane-bound Fas (CD95) ligand to its soluble form is associated with downregulation of its proapoptotic activity and loss of liver toxicity. J Exp Med 187: 1205-1213, 1998

24. Holler N, Tardivel A, Kovacsovics-Bankowski M, Hertig S, Gaide O, Martinon F, Tinel A, Deperthes D, Calderara S, Schulthess T, Engel J, Schneider P and Tschopp J: Two adjacent trimeric Fas ligands are required for Fas signaling and formation of a death-inducing signaling complex. Mol Cell Biol 23: 1428-1440, 2003.

25. Meza-Lamas E, Bollain-y-Goytia JJ, Ramirez-Sandoval R, Sanchez-Rodriguez SH, Lopez-Robles E, Avalos-Diaz E and Herrera-Esparza R: Camptothecin induces the transit of FasL trimers to the cell surface in apoptotic HEp-2 cells. Cell Mol Biol Lett 11: 299-311, 2006.

26. Stravopodis DJ, Margaritis LH and Voutsinas GE: Drug-mediated targeted disruption of multiple protein activities through functional inhibition of the hsp90 chaperone complex. Curr Med Chem 14: 3122-3138, 2007.

27. Whitesell L and Lindquist SL: HSP90 and the chaperoning of cancer. Nat Rev Cancer 5: 761-772, 2005.

28. Blagg BS and Kerr TD: Hsp90 inhibitors: small molecules that transform the Hsp90 protein folding machinery into a catalyst for protein degradation. Med Res Rev 26: 310-338, 2006.

29. Collins I, Weber A and Levens D: Transcriptional consequences of topoisomerase inhibition. Mol Cell Biol 21: 8437-8451, 2001.

30. Drolet M, Bi X and Liu LF: Hypernegative supercoiling of the DNA template during transcription elongation in vitro. J Biol Chem 269: 2068-2074, 1994

31. Fesik SW: Promoting apoptosis as a strategy for cancer drug discovery. Nat Rev Cancer 5: 876-885, 2005.

32. Johnstone RW, Ruefli AA and Lowe SW: Apoptosis: a link between cancer genetics and chemotherapy. Cell 108: 153-164, 2002

33. Pommier Y, Sordet O, Antony S, Hayward RL and Kohn KW: Apoptosis defects and chemotherapy resistance: molecular interaction maps and networks. Oncogene 23: 2934-2949, 2004.

34. Meng XW, Lee SH and Kaufmann SH: Apoptosis in the treatment of cancer: a promise kept? Curr Opin Cell Biol 18: 668-676, 2006

35. Robert J, Vekris A, Pourquier P and Bonnet J: Predicting drug response based on gene expression. Crit Rev Oncol Hematol 51: 205-227, 2004

36. Valkov NI and Sullivan DM: Tumor p53 status and response to topoisomerase II inhibitors. Drug Resist Update 6: 27-39, 2003.

37. Coradini D and Daidone MG: Biomolecular prognostic factors in breast cancer. Curr Opin Obstet Gynecol 16: 49-55, 2004.

38. Singhal S, Vachani A, Antin-Ozerkis D, Kaiser LR and Albelda SM: Prognostic implications of cell cycle, apoptosis, and angiogenesis biomarkers in non-small cell lung cancer: a review. Clin Cancer Res 11: 3974-3986, 2005.

39. Peters MG, Vidal Mdel C, Gimenez L, Mauro L, Armanasco E, Cresta C, Bal de Kier Joffe E and Puricelli L: Prognostic value of cell cycle regulator molecules in surgically resected stage I and II breast cancer. Oncol Rep 12: 1143-1150, 2004

40. Harada H, Omura K, Nakajima Y, Hasegawa S and Mogi S: Cyclin B1 is useful to predict occult cervical lymph node metastases in tongue carcinoma. J Exp Clin Cancer Res 25: 351-356, 2006.

41. Yasui W, Oue N, Aung PP, Matsumura S, Shutoh M and Nakayama H: Molecular-pathological prognostic factors of gastric cancer: a review. Gastric Cancer 8: 86-94, 2005.

42. Porter PL, Barlow WE, Yeh IT, Lin MG, Yuan XP, Donato E, Sledge GW, Shapiro CL, Ingle JN, Haskell CM, Albain KS, Roberts JM, Livingston RB and Hayes DF: p27(Kip1) and cyclin $\mathrm{E}$ expression and breast cancer survival after treatment with adjuvant chemotherapy. J Natl Cancer Inst 98: 1723-1731, 2006
43. Obermann EC, Went P, Pehrs AC, Tzankov A, Wild PJ, Pileri S, Hofstaedter F and Dirnhofer S: Cyclin B1 expression is an independent prognostic marker for poor outcome in diffuse large B-cell lymphoma. Oncol Rep 14: 1461-1467, 2005.

44. Skalicky DA, Kench JG, Segara D, Coleman MJ, Sutherland RL, Henshall SM, Musgrove EA and Biankin AV: Cyclin E expression and outcome in pancreatic ductal adenocarcinoma. Cancer Epidemiol Biomarkers Prev 15: 1941-1947, 2006.

45. Igarashi T, Jiang SX, Kameya T, Asamura H, Sato Y, Nagai K and Okayasu I: Divergent cyclin B1 expression and Rb/p16/ cyclin D1 pathway aberrations among pulmonary neuroendocrine tumors. Mod Pathol 17: 1259-1267, 2004.

46. Lee H, Park G, Jung JH, Ahn WS, Lee JM, Kim BK and Kang CS: Diagnostic approach using the expression profiling of the P53 tumor suppressor gene and its related proteins in ovarian epithelial tumors. Int J Gynecol Cancer 15: 453-461, 2005.

47. Dan S and Yamori T: Repression of cyclin B1 expression after treatment with adriamycin, but not cisplatin in human lung cancer A549 cells. Biochem Biophys Res Commun 280: 861-867, 2001.

48. Bar-On O, Shapira M and Hershko DD: Differential effects of doxorubicin treatment on cell cycle arrest and Skp2 expression in breast cancer cells. Anticancer Drugs 18: 1113-1121, 2007.

49. Yoon KA, Ku JL, Yang JO and Park JG: Telomerase activity, expression of $\mathrm{Bcl}-2$ and cell cycle regulation in doxorubicin resistant gastric carcinoma cell lines. Int J Mol Med 11: 343-348, 2003.

50. Cooper MJ, Haluschak JJ, Johnson D, Schwartz S, Morrison LJ, Lippa M, Hatzivassiliou G and Tan J: p53 mutations in bladder carcinoma cell lines. Oncol Res 6: 569-579, 1994.

51. Sanchez-Carbayo M, Socci ND, Charytonowicz E, Lu M, Prystowsky M, Childs G and Cordon-Cardo C: Molecular profiling of bladder cancer using cDNA microarrays: defining histogenesis and biological phenotypes. Cancer Res 62: 6973-6980, 2002.

52. Lukas J, Lukas C and Bartek J: Mammalian cell cycle checkpoints: signalling pathways and their organization in space and time. DNA Repair (Amst) 3: 997-1007, 2004.

53. Melino G, Bernassola F, Ranalli M, Yee K, Zong WX, Corazzari M, Knight RA, Green DR, Thompson C and Vousden KH: p73 induces apoptosis via PUMA transactivation and Bax mitochondrial translocation. J Biol Chem 279: 8076-8083, 2004

54. Deyoung MP and Ellisen LW: p63 and p73 in human cancer: defining the network. Oncogene 26: 5169-5183, 2007.

55. Vayssade M, Haddada H, Faridoni-Laurens L, Tourpin S, Valent A, Benard J and Ahomadegbe JC: P73 functionally replaces p53 in adriamycin-treated, p53-deficient breast cancer cells. Int J Cancer 116: 860-869, 2005.

56. Rocco JW, Leong CO, Kuperwasser N, DeYoung MP and Ellisen LW: p63 mediates survival in squamous cell carcinoma by suppression of p73-dependent apoptosis. Cancer Cell 9: 45-56, 2006.

57. Kim HS, Lee JW, Soung YH, Park WS, Kim SY, Lee JH, Park JY, Cho YG, Kim CJ, Jeong SW, Nam SW, Kim SH, Lee JY, Yoo NJ and Lee SH: Inactivating mutations of caspase-8 gene in colorectal carcinomas. Gastroenterology 125: 708-715, 2003.

58. Mandruzzato S, Brasseur F, Andry G, Boon T and van der Bruggen P: A CASP-8 mutation recognized by cytolytic T lymphocytes on a human head and neck carcinoma. J Exp Med 186: 785-793, 1997.

59. Teitz T, Wei T, Valentine MB, Vanin EF, Grenet J, Valentine VA, Behm FG, Look AT, Lahti JM and Kidd VJ: Caspase 8 is deleted or silenced preferentially in childhood neuroblastomas with amplification of MYCN. Nat Med 6: 529-535, 2000.

60. Hopkins-Donaldson S, Ziegler A, Kurtz S, Bigosch C, Kandioler D, Ludwig C, Zangemeister-Wittke U and Stahel R: Silencing of death receptor and caspase- 8 expression in small cell lung carcinoma cell lines and tumors by DNA methylation. Cell Death Differ 10: 356-364, 2003.

61. Pingoud-Meier C, Lang D, Janss AJ, Rorke LB, Phillips PC, Shalaby $\mathrm{T}$ and Grotzer MA: Loss of caspase- 8 protein expression correlates with unfavorable survival outcome in childhood medulloblastoma. Clin Cancer Res 9: 6401-6409, 2003.

62. Harada K, Toyooka S, Shivapurkar N, Maitra A, Reddy JL, Matta H, Miyajima K, Timmons CF, Tomlinson GE, Mastrangelo D, Hay RJ, Chaudhary PM and Gazdar AF: Deregulation of caspase 8 and 10 expression in pediatric tumors and cell lines. Cancer Res 62: 5897-5901, 2002. 
63. Vargo-Gogola T, Crawford HC, Fingleton B and Matrisian LM: Identification of novel matrix metalloproteinase-7 (matrilysin) cleavage sites in murine and human Fas ligand. Arch Biochem Biophys 408: 155-161, 2002.

64. Wang WS, Chen PM, Wang HS, Liang WY and Su Y: Matrix metalloproteinase-7 increases resistance to Fas-mediated apoptosis and is a poor prognostic factor of patients with colorectal carcinoma. Carcinogenesis 27: 1113-1120, 2006.

65. Backes C, Kuentzer J, Lenhof HP, Comtesse N and Meese E: GraBCas: a bioinformatics tool for score-based prediction of Caspase- and Granzyme B-cleavage sites in protein sequences. Nucleic Acids Res 33: W208-W213, 2005.

66. Gausdal G, Gjertsen BT, Fladmark KE, Demol H, Vandekerckhove J and Doskeland SO: Caspase-dependent, geldanamycin-enhanced cleavage of co-chaperone p23 in leukemic apoptosis. Leukemia 18: 1989-1996, 2004.

67. Bredemeyer AJ, Carrigan PE, Fehniger TA, Smith DF and Ley TJ: Hop cleavage and function in granzyme B-induced apoptosis. J Biol Chem 281: 37130-37141, 2006.

68. Hostetter DR, Loeb CR, Chu F and Craik CS: Hip is a prosurvival substrate of granzyme B. J Biol Chem 282: 27865-27874, 2007.

69. Tozser J, Bagossi P, Zahuczky G, Specht SI, Majerova E and Copeland TD: Effect of caspase cleavage-site phosphorylation on proteolysis. Biochem J 372: 137-143, 2003.

70. Kamal A, Thao L, Sensintaffar J, Zhang L, Boehm MF, Fritz LC and Burrows FJ: A high-affinity conformation of Hsp90 confers tumour selectivity on Hsp90 inhibitors. Nature 425: 407-410, 2003.

71. Rhodes DR, Kalyana-Sundaram S, Tomlins SA, Mahavisno V, Kasper N, Varambally R, Barrette TR, Ghosh D, Varambally S and Chinnaiyan AM: Molecular concepts analysis links tumors, pathways, mechanisms, and drugs. Neoplasia 9: 443-454, 2007.

72. Dyrskjot L, Zieger K, Kruhoffer M, Thykjaer T, Jensen JL, Primdahl H, Aziz N, Marcussen N, Moller K and Orntoft TF: A molecular signature in superficial bladder carcinoma predicts clinical outcome. Clin Cancer Res 11: 4029-4036, 2005.

73. Parissenti AM, Hembruff SL, Villeneuve DJ, Veitch Z, Guo B and Eng J: Gene expression profiles as biomarkers for the prediction of chemotherapy drug response in human tumour cells. Anticancer Drugs 18: 499-523, 2007.

74. O'Connell J, Bennett MW, O'Sullivan GC, O'Callaghan J, Collins JK and Shanahan F: Expression of Fas (CD95/APO-1) ligand by human breast cancers: significance for tumor immune privilege. Clin Diagn Lab Immunol 6: 457-463, 1999.

75. Herrnring C, Reimer T, Jeschke U, Makovitzky J, Kruger K, Gerber B, Kabelitz D and Friese K: Expression of the apoptosisinducing ligands FasL and TRAIL in malignant and benign human breast tumors. Histochem Cell Biol 113: 189-194, 2000

76. Lee SH, Shin MS, Lee JY, Park WS, Kim SY, Jang JJ, Dong SM, $\mathrm{Na}$ EY, Kim CS, Kim SH and Yoo NJ: In vivo expression of soluble Fas and FAP-1: possible mechanisms of Fas resistance in human hepatoblastomas. J Pathol 188: 207-212, 1999.

77. Sugahara K, Yamada Y, Hiragata Y, Matsuo Y, Tsuruda K, Tomonaga M, Maeda T, Atogami S, Tsukasaki K and Kamihira S: Soluble and membrane isoforms of Fas/CD95 in fresh adult T-cell leukemia (ATL) cells and ATL-cell lines. Int J Cancer 72: $128-132,1997$.

78. Lickliter JD, Kratzke RA, Nguyen PL, Niehans GA and Miller JS: Fas ligand is highly expressed in acute leukemia and during the transformation of chronic myeloid leukemia to blast crisis. Exp Hematol 27: 1519-1527, 1999.

79. Shima Y, Nishimoto N, Yoshizaki K and Kishimoto T: Fas antigen/APO-1 (CD95) expression on myeloma cells. Leuk Lymphoma 23: 521-531, 1996.

80. Reimer T, Herrnring C, Koczan D, Richter D, Gerber B, Kabelitz D, Friese K and Thiesen HJ: FasL:Fas ratio - a prognostic factor in breast carcinomas. Cancer Res 60: 822-828, 2000.

81. Yamana K, Bilim V, Hara N, Kasahara T, Itoi T, Maruyama R, Nishiyama T, Takahashi K and Tomita Y: Prognostic impact of FAS/CD95/APO-1 in urothelial cancers: decreased expression of Fas is associated with disease progression. $\mathrm{Br} \mathrm{J}$ Cancer 93: 544-551, 2005

82. Yoshimoto Y, Kawada M, Ikeda D and Ishizuka M: Involvement of doxorubicin-induced Fas expression in the antitumor effect of doxorubicin on Lewis lung carcinoma in vivo. Int Immunopharmacol 5: 281-288, 2005 .
83. Botti C, Buglioni S, Benevolo M, Giannarelli D, Papaldo P, Cognetti F, Vici P, Di Filippo F, Del Nonno F, Venanzi FM, Natali PG and Mottolese M: Altered expression of FAS system is related to adverse clinical outcome in stage I-II breast cancer patients treated with adjuvant anthracycline-based chemotherapy. Clin Cancer Res 10: 1360-1365, 2004.

84. Mo YY and Beck WT: DNA damage signals induction of fas ligand in tumor cells. Mol Pharmacol 55: 216-222, 1999.

85.Perabo FG, Kamp S, Schmidt D, Lindner H, Steiner G, Mattes RH, Wirger A, Pegelow K, Albers P, Kohn EC, von Ruecker A and Mueller SC: Bladder cancer cells acquire competent mechanisms to escape Fas-mediated apoptosis and immune surveillance in the course of malignant transformation. Br J Cancer 84: 1330-1338, 2001.

86. Shiraki K, Yamanaka T, Inoue H, Kawakita T, Enokimura N, Okano H, Sugimoto K, Murata K and Nakano T: Expression of TNF-related apoptosis-inducing ligand in human hepatocellular carcinoma. Int J Oncol 26: 1273-1281, 2005.

87. Ashkenazi A and Dixit VM: Death receptors: signaling and modulation. Science 281: 1305-1308, 1998

88. Inoue H, Shiraki K, Yamanaka T, Ohmori S, Sakai T, Deguchi M, Okano H, Murata K, Sugimoto K and Nakano T: Functional expression of tumor necrosis factor-related apoptosisinducing ligand in human colonic adenocarcinoma cells. Lab Invest 82: 1111-1119, 2002

89. Chen G, Sircar K, Aprikian A, Potti A, Goltzman D and Rabbani SA: Expression of RANKL/RANK/OPG in primary and metastatic human prostate cancer as markers of disease stage and functional regulation. Cancer 107: 289-298, 2006.

90. Mizutani Y, Matsubara H, Yamamoto K, Nan Li Y, Mikami K, Okihara K, Kawauchi A, Bonavida B and Miki T: Prognostic significance of serum osteoprotegerin levels in patients with bladder carcinoma. Cancer 101: 1794-1802, 2004.

91. Garcia N, Salamanca F, Astudillo-De la Vega H, CurielQuesada E, Alvarado I, Penaloza R and Arenas D: A molecular analysis by gene expression profiling reveals Bik/NBK overexpression in sporadic breast tumor samples of Mexican females. BMC Cancer 5: 93, 2005.

92.Lu Y, Lemon W, Liu PY, Yi Y, Morrison C, Yang P, Sun Z, Szoke J, Gerald WL, Watson M, Govindan R and You M: A gene expression signature predicts survival of patients with stage I non-small cell lung cancer. PLoS Med 3: e467, 2006 .

93. Marchet A, Mocellin S, Belluco C, Ambrosi A, De Marchi F, Mammano E, Digito M, Leon A, D'Arrigo A, Lise M and Nitti D: Gene expression profile of primary gastric cancer: towards the prediction of lymph node status. Ann Surg Oncol 14: 1058-1064, 2007.

94. Sturm I, Stephan C, Gillissen B, Siebert R, Janz M, Radetzki S, Jung K, Loening S, Dorken B and Daniel PT: Loss of the tissuespecific proapoptotic BH3-only protein Nbk/Bik is a unifying feature of renal cell carcinoma. Cell Death Differ 13: 619-627, 2006.

95. Bredel M, Bredel C, Juric D, Harsh GR, Vogel H, Recht LD and Sikic BI: High-resolution genome-wide mapping of genetic alterations in human glial brain tumors. Cancer Res 65: 4088-4096, 2005.

96. Kim TY, Zhong S, Fields CR, Kim JH and Robertson KD: Epigenomic profiling reveals novel and frequent targets of aberrant DNA methylation-mediated silencing in malignant glioma. Cancer Res 66: 7490-7501, 2006.

97.Panaretakis T, Pokrovskaja K, Shoshan MC and Grander D: Activation of $\mathrm{Bak}, \mathrm{Bax}$, and $\mathrm{BH} 3$-only proteins in the apoptotic response to doxorubicin. J Biol Chem 277: 44317-44326, 2002.

98. Hur J, Bell DW, Dean KL, Coser KR, Hilario PC, Okimoto RA, Tobey EM, Smith SL, Isselbacher KJ and Shioda T: Regulation of expression of BIK proapoptotic protein in human breast cancer cells: p53-dependent induction of BIK mRNA by fulvestrant and proteasomal degradation of BIK protein. Cancer Res 66: 10153-10161, 2006

99. Mathai JP, Germain M and Shore GC: BH3-only BIK regulates BAX, BAK-dependent release of $\mathrm{Ca}^{2+}$ from endoplasmic reticulum stores and mitochondrial apoptosis during stressinduced cell death. J Biol Chem 280: 23829-23836, 2005.

100. Real PJ, Sanz C, Gutierrez O, Pipaon C, Zubiaga AM and Fernandez-Luna JL: Transcriptional activation of the proapoptotic bik gene by E2F proteins in cancer cells. FEBS Lett 580: 5905-5909, 2006. 
101. Hsu SY and Hsueh AJ: A splicing variant of the Bcl-2 member Bok with a truncated $\mathrm{BH} 3$ domain induces apoptosis but does not dimerize with antiapoptotic $\mathrm{Bcl}-2$ proteins in vitro. J Biol Chem 273: 30139-30146, 1998.

102. Chung TK, Cheung TH, Lo WK, Yim SF, Yu MY, Krajewski S, Reed JC and Wong YF: Expression of apoptotic regulators and their significance in cervical cancer. Cancer Lett 180: 63-68, 2002.

103. Batinac T, Zamolo G, Coklo M, Hadzisejdic I, Stemberger C and Zauhar G: Expression of cell cycle and apoptosis regulatory proteins in keratoacanthoma and squamous cell carcinoma. Pathol Res Pract 202: 599-607, 2006.

104. Kawauchi S, Fukuda T, Oda Y, Saito T, Oga A, Takeshita M, Yokoyama K, Chuman H, Iwamoto Y, Sasaki K and Tsuneyoshi M: Prognostic significance of apoptosis in synovial sarcoma: correlation with clinicopathologic parameters, cell proliferative activity, and expression of apoptosis-related proteins. Mod Pathol 13: 755-765, 2000.

105. O'Kane SL, Pound RJ, Campbell A, Chaudhuri N, Lind MJ and Cawkwell L: Expression of bcl-2 family members in malignant pleural mesothelioma. Acta Oncol 45: 449-453, 2006.

106. Smith L, Berrieman HK, O'Kane SL, Campbell A, Maraveyas A and Cawkwell L: Immunohistochemical detection of apoptotic markers in gastric cancer. Oncol Res 15: 441-444, 2006.

107. Berrieman HK, Smith L, O'Kane SL, Campbell A, Lind MJ and Cawkwell L: The expression of Bcl-2 family proteins differs between non small cell lung carcinoma subtypes. Cancer 103: 1415-1419, 2005

108. Pal'tsev MA, Demura SA, Kogan EA, Jaques G and Zende B: Role of Bcl-2, Bax, and Bak in spontaneous apoptosis and proliferation in neuroendocrine lung tumors: immunohistochemical study. Bull Exp Biol Med 130: 697-700, 2000.

109. Fecker LF, Geilen CC, Tchernev G, Trefzer U, Assaf C, Kurbanov BM, Schwarz C, Daniel PT and Eberle J: Loss of proapoptotic $\mathrm{Bcl}-2$-related multidomain proteins in primary melanomas is associated with poor prognosis. J Invest Dermatol 126: 1366-1371, 2006.

110. Bosanquet AG, Sturm I, Wieder T, Essmann F, Bosanquet MI, Head DJ, Dorken B and Daniel PT: Bax expression correlates with cellular drug sensitivity to doxorubicin, cyclophosphamide and chlorambucil but not fludarabine, cladribine or corticosteroids in B cell chronic lymphocytic leukemia. Leukemia 16: 1035-1044, 2002.

111. Bellarosa D, Ciucci A, Bullo A, Nardelli F, Manzini S, Maggi CA and Goso C: Apoptotic events in a human ovarian cancer cell line exposed to anthracyclines. J Pharmacol Exp Ther 296: 276-283, 2001

112. Suzuki F, Hashimoto K, Kikuchi H, Nishikawa H, Matsumoto H, Shimada J, Kawase M, Sunaga K, Tsuda T, Satoh K and Sakagami H: Induction of tumor-specific cytotoxicity and apoptosis by doxorubicin. Anticancer Res 25: 887-893, 2005

113. Gao S, Fu W, Durrenberger M, De Geyter C and Zhang H: Membrane translocation and oligomerization of hBok are triggered in response to apoptotic stimuli and Bnip3. Cell Mol Life Sci 62: 1015-1024, 2005.

114. Szende B, Arvai K, Petak I, Nagy K, Vegso G and Perner F: Changes in gene expression in the course of proliferative processes in the parathyroid gland. Magy Onkol 50: 137-140, 2006.

115. Yakovlev AG, Di Giovanni S, Wang G, Liu W, Stoica B and Faden AI: BOK and NOXA are essential mediators of $\mathrm{p} 53$ dependent apoptosis. J Biol Chem 279: 28367-28374, 2004.

116. Tsujimoto Y, Finger LR, Yunis J, Nowell PC and Croce CM: Cloning of the chromosome breakpoint of neoplastic B cells with the $t(14 ; 18)$ chromosome translocation. Science 226: 1097-1099, 1984

117. Ben-Ezra JM, Kornstein MJ, Grimes MM and Krystal G: Small cell carcinomas of the lung express the Bcl-2 protein. Am J Pathol 145: 1036-1040, 1994.

118. Schena M, Larsson LG, Gottardi D, Gaidano G, Carlsson M, Nilsson K and Caligaris-Cappio F: Growth- and differentiationassociated expression of bcl-2 in B-chronic lymphocytic leukemia cells. Blood 79: 2981-2989, 1992

119. Harada N, Hata H, Yoshida M, Soniki T, Nagasaki A Kuribayashi N, Kimura T, Matsuzaki $\mathrm{H}$ and Mitsuya $\mathrm{H}$ : Expression of Bcl-2 family of proteins in fresh myeloma cells. Leukemia 12: 1817-1820, 1998

120. Leiter U, Schmid RM, Kaskel P, Peter RU and Krahn G: Antiapoptotic bcl-2 and bcl-xL in advanced malignant melanoma. Arch Dermatol Res 292: 225-232, 2000.
121. Ye D, Li H, Qian S, Sun Y, Zheng J and Ma Y: bcl-2/bax expression and p53 gene status in human bladder cancer: relationship to early recurrence with intravesical chemotherapy after resection. J Urol 160: 2025-2029, 1998.

122. Matsushima H, Kitamura T, Goto T, Hosaka Y, Homma Y and Kawabe K: Combined analysis with Bcl-2 and P53 immunostaining predicts poorer prognosis in prostatic carcinoma. J Urol 158: 2278-2283, 1997 .

123. Mano Y, Kikuchi Y, Yamamoto K, Kita T, Hirata J, Tode T, Ishii $\mathrm{K}$ and Nagata I: Bcl-2 as a predictor of chemosensitivity and prognosis in primary epithelial ovarian cancer. Eur J Cancer 35: 1214-1219, 1999

124. Rajkumar T, Rajan S, Baruah RK, Majhi U, Selvaluxmi G and Vasanthan A: Prognostic significance of Bcl-2 and p53 protein expression in stage IIB and IIIB squamous cell carcinoma of the cervix. Eur J Gynaecol Oncol 19: 556-560, 1998.

125. Nakata B, Muguruma K, Hirakawa K, Chung YS, Yamashita Y, Inoue T, Matsuoka T, Onoda N, Kato Y and Sowa M: Predictive value of $\mathrm{Bcl}-2$ and Bax protein expression for chemotherapeutic effect in gastric cancer. A pilot study. Oncology 55: 543-547, 1998.

126. Lipponen P, Pietilainen T, Kosma VM, Aaltomaa S, Eskelinen M and Syrjanen K: Apoptosis suppressing protein bcl-2 is expressed in well-differentiated breast carcinomas with favourable prognosis. J Pathol 177: 49-55, 1995.

127. Sinicrope FA, Hart J, Michelassi F and Lee JJ: Prognostic value of bcl-2 oncoprotein expression in stage II colon carcinoma. Clin Cancer Res 1: 1103-1110, 1995.

128. Gazzaniga P, Gradilone A, Giuliani L, Gandini O, Silvestri I, Nofroni I, Saccani G, Frati L and Agliano AM: Expression and prognostic significance of LIVIN, SURVIVIN and other apoptosis-related genes in the progression of superficial bladder cancer. Ann Oncol 14: 85-90, 2003.

129. Kirsh EJ, Baunoch DA and Stadler WM: Expression of bcl-2 and bcl-X in bladder cancer. J Urol 159: 1348-1353, 1998.

130. Ong F, Moonen LM, Gallee MP, ten Bosch C, Zerp SF, Hart AA, Bartelink $\mathrm{H}$ and Verheij M: Prognostic factors in transitional cell cancer of the bladder: an emerging role for Bcl-2 and p53. Radiother Oncol 61: 169-175, 2001.

131.Park SS, Kim MA, Eom YW and Choi KS: Bcl-xL blocks high dose doxorubicin-induced apoptosis but not low dose doxorubicin-induced cell death through mitotic catastrophe. Biochem Biophys Res Commun 363: 1044-1049, 2007.

132. Basolo F, Fiore L, Fusco A, Giannini R, Albini A, Merlo GR, Fontanini G, Conaldi PG and Toniolo A: Potentiation of the malignant phenotype of the undifferentiated ARO thyroid cell line by insertion of the bcl-2 gene. Int J Cancer 81: 956-962, 1999.

133. Mitsiades CS, Hayden P, Kotoula V, McMillin DW McMullan C, Negri J, Delmore JE, Poulaki V and Mitsiades N: $\mathrm{Bcl}-2$ overexpression in thyroid carcinoma cells increases sensitivity to bcl-2 homology 3 domain inhibition. J Clin Endocrinol Metab 92: 4845-4852, 2007.

134. Bilim VN, Tomita Y, Kawasaki T, Takeda M and Takahashi K: Variable Bcl-2 phenotype in benign and malignant lesions of urothelium. Cancer Lett 128: 87-92, 1998.

135. Bilim V, Kasahara T, Noboru H, Takahashi K and Tomita Y: Caspase involved synergistic cytotoxicity of bcl-2 antisense oligonucleotides and adriamycin on transitional cell cancer cells. Cancer Lett 155: 191-198, 2000.

136.Jiang M, Wei Q, Wang J, Du Q, Yu J, Zhang L and Dong Z: Regulation of PUMA-alpha by p53 in cisplatin-induced renal cell apoptosis. Oncogene 25: 4056-4066, 2006.

137. Chipuk JE, Bouchier-Hayes L, Kuwana T, Newmeyer DD and Green DR: PUMA couples the nuclear and cytoplasmic proapoptotic function of p53. Science 309: 1732-1735, 2005.

138. Chaturvedi V, Sitailo LA, Qin JZ, Bodner B, Denning MF, Curry J, Zhang W, Brash D and Nickoloff BJ: Knockdown of p53 levels in human keratinocytes accelerates Mcl-1 and Bcl-x(L) reduction thereby enhancing UV-light induced apoptosis. Oncogene 24: 5299-5312, 2005.

139. Deveraux QL, Takahashi R, Salvesen GS and Reed JC: X-linked IAP is a direct inhibitor of cell-death proteases. Nature 388: 300-304, 1997.

140. Takahashi R, Deveraux Q, Tamm I, Welsh K, Assa-Munt N, Salvesen GS and Reed JC: A single BIR domain of XIAP sufficient for inhibiting caspases. J Biol Chem 273: 7787-7790, 1998.

141. Altieri DC: The case for survivin as a regulator of microtubule dynamics and cell-death decisions. Curr Opin Cell Biol 18: 609-615, 2006 
142.Tamm I, Wang Y, Sausville E, Scudiero DA, Vigna N, Oltersdorf $\mathrm{T}$ and Reed JC: IAP-family protein survivin inhibits caspase activity and apoptosis induced by Fas (CD95), Bax, caspases, and anticancer drugs. Cancer Res 58: 5315-5320, 1998.

143.Li QX, Zhao J, Liu JY, Jia LT, Huang HY, Xu YM, Zhang Y, Zhang R, Wang CJ, Yao LB, Chen SY and Yang AG: Survivin stable knockdown by siRNA inhibits tumor cell growth and angiogenesis in breast and cervical cancers. Cancer Biol Ther 5: 860-866, 2006.

144. Hinnis AR, Luckett JC and Walker RA: Survivin is an independent predictor of short-term survival in poor prognostic breast cancer patients. Br J Cancer 96: 639-645, 2007.
145. Stauber RH, Mann W and Knauer SK: Nuclear and cytoplasmic survivin: molecular mechanism, prognostic, and therapeutic potential. Cancer Res 67: 5999-6002, 2007.

146. Altieri DC: Survivin, cancer networks and pathway-directed drug discovery. Nat Rev Cancer 8: 61-70, 2008.

147. Smith SD, Wheeler MA, Plescia J, Colberg JW, Weiss RM and Altieri DC: Urine detection of survivin and diagnosis of bladder cancer. JAMA 285: 324-328, 2001.

148. Rosa J, Canovas P, Islam A, Altieri DC and Doxsey SJ: Survivin modulates microtubule dynamics and nucleation throughout the cell cycle. Mol Biol Cell 17: 1483-1493, 2006. 